\title{
CAMÕES E TARTESSOS: LEITURAS EM TORNO DE DOIS EXCERTOS D'OS LUSÍADAS
}

\section{CAMÕES AND TARTESSOS: READING AROUND TWO EXCERPTS OF THE LUSIADS}

\author{
PEDRO ALBUQUERQUE*
}

À Professora Annabela Rita, por me ter encorajado a perseguir os meus sonhos.

À Dudu.

Resumen: Luís Vaz de Camões, no poema épico Os Lusíadas, refere os Campos Tartésios (III, 100) e o rio Tarteso (VIII, 29). O objectivo deste artigo é explicar a presença destas referências geográficas no poema, analisando a vida do poeta $(\mathrm{e}$ as discussões em torno desta) e a sua relação com o contexto cultural e intelectual no Portugal do século XVI, bem como alguns aspectos da construção deste brilhante testemunho da literatura portuguesa. Após a discussão deste contexto, analisa-se a discussão em torno das fontes clássicas, portuguesas e espanholas que, provavelmente, o autor utilizou para escrever o poema, o que é comparado com as poucas informações que detemos quando tentamos reconstruir a vida do poeta. Neste sentido, é provável que Camões tenha adquirido alguns conhecimentos na Índia e não apenas em Portugal. Concluise que as prováveis fontes para Tartessos n'Os Lusíadas são o Dictionarium de A. A. Nebrija e o Libro de Grandezas y cosas memorables de España, de Pedro de Medina, escrito em 1548 (i.e., antes da partida de Camões para a Índia), especialmente o primeiro na versão latina do termo (tartessus/ tartessius). Analisam-se, igualmente, as regras da métrica que, provavelmente, obrigaram o poeta a incluir, n'Os Lusíadas III, 100 e VIII, 29, os termos campos tartésios (uma alternativa

* Arqueólogo. Bolseiro da Fundação para a Ciência e Tecnologia, na UNIARQ (Centro de Arqueologia da Universidade de Lisboa). Gostaria de agradecer a várias pessoas que tornaram este trabalho possível e aliciante: Ana Margarida Arruda, que me sugeriu o tema e me encorajou a desenvolvê-lo; a Rui Morais, pelos seus preciosos apontamentos à minha dissertação de Mestrado (Albuquerque, 2008); a José a campos de Tarifa) e Tarteso (uma alternativa a Guadalquivir, Bétis e outros sinónimos utilizados no poema). Do ponto de vista historiográfico, Camões não estava interessado neste tema, uma vez que tenta, primeiro, dar ao seu país uma espécie de identidade colectiva e uma mensagem nacionalista (Lusíadas $=$ filhos de Luso). Estas referências levam-nos a incluir Camões na história da recepção de Tartessos na historiografia ibérica.

Palavras - chave: Luís de Camões; Tartessos; Fontes; Nebrija; Pedro de Medina; Métrica; Historiografia.

Abstract: Luís Vaz de Camões, in the epic poem Os Lusíadas, refers the tartessian fields (III, 100), and the river Tartessus. The aim of this paper is to explain the presence of these geographical references in the poem, analyzing the poet's life (and the discussions around it) and his relationship to the Portuguese cultural and intellectual context in the 16th Century, as well as some aspects of the construction of this brilliant testimony of the Portuguese literature. After the definition of this context, we analyze the discussion about the classical, Portuguese and Spanish sources that the poet probably used to write the poem, which is compared to the scarce Américo Costa Ramalho, pelos sábios conselhos para esta investigação. A Manuel Álvarez Martí-Aguilar, por ter fornecido dois admiráveis trabalhos. Finalmente, ao meu irmão, cunhada, mãe e pai, por todo o apoio, carinho e paciência em todos os meus momentos. Todas as imprecisões deste trabalho devem-se, sobretudo, ao seu autor. 
information that we deal with, when we try to reconstruct the poet's life. In this context, it's probable that Camões could have acquired some knowledge in India and not only in Portugal. We reach the conclusion that the probable sources for Tartessus in Os Lusiadas were the A. A. Nebrija's Dictionarium and Pedro de Medina's Libro de Grandezas, wrote in 1548 (i.e., before Camões' departure to India), especially the first one in the latin version of this word (Tartessus/ Tartessius). We analyze as well the metrical rules that, probably, forced the poet to include in Os Lusiadas III, 100 and VIII,
29 the words campos tartésios (an alternative to campos de Tarifa) and Tarteso (an alternative to Guadalquivir, Betis and other synonyms used in the poem). In the historiographical point of view, Camões was not interested in this theme, because he tries, first, to give to his country a kind of identity and a nationalist message (Lusíadas $=$ sons of Lusus). These references lead us to include Camões in the history of the reception of Tartessus in Iberian historiography.

Key words: Luís de Camões; Tartessus; Sources; Nebrija; Pedro de Medina; Metrics; Historiography

\section{NOTA INICIAL}

«Nunca com Semiramis gente tanta/ veio os Campos idáspicos enchendo;/ nem Atila, que Itália toda espanta,/ chamando-se de Deus açoute horrendo,/ Gótica gente trouxe tanta, quanta/ do Sarraceno bárbaro, estupendo,/ co'o poder excessivo de Granada,/ Foi nos campos tartésios ajuntada»

Os Lusíadas, III, 100

«Olha, por seu conselho e ousadia,/ de Deus guiada só e de santa estrela,/ só pode ver o que impossíbil parecia:/ vencer o povo ingente de Castela./ Vês, por indústria, esforço e valentia,/ outro estrago e vitória clara e bela/ na gente, assi feroz como infinita,/ que entre o Tarteso e Guadiana habita?»

Os Lusíadas VIII, 29

Estes excertos d'Os Lusíadas motivaram a realização de um estudo que, como o título indica, consiste numa série de leituras que podem ser feitas sobre o significado da inclusão de Tartessos no maior testemunho literário português.

Quando abordamos um autor como Luis Vaz de Camões (=LC), um primeiro aspecto a considerar é a copiosa bibliografia de leituras críticas e de perspectivas que se debruçaram sobre a sua obra, desde a publicação da «Edição Princeps» d'Os Lusíadas em $1572^{1}$. Durante estes quatrocentos anos, foram múltiplos os olhares e interpretações que se lançaram sobre os 8816

1. Veja-se, por exemplo, a quantidade de títulos, adiante citados, publicados em 1972 e 1980 e inscritos, respectivamente, nas celebrações da publicação do poema e da morte do poeta (Fig. 1), sistematizadas em obras como, por exemplo, Exposições bibliográficas, como a de 1972, organizada por J.V. de Pina Martins, bem como outras compilações (Correia, 1985; Matos, 1995, e AAVV, 1980). Vejase, nesta última referência, a quantidade de edições do poema publicadas até 1980. Para este trabalho, consultaram-se as edições de Emanuel Paulo Ramos (2000, da Porto Editora), de Hernâni Cidade (publicada pela RBA editores em 2005) e, para aspectos pontuais, as edições fac-similadas d'Os Lusíadas, com comentários de Faria e Sousa, bem como de Epifânio da Silva Dias (ambas de 1972). versos desta obra, distribuídos em dez Cantos, não estando ao alcance deste trabalho e do seu autor uma exposição mais detalhada da recepção da obra camoniana. Esta pode dividir-se em três fases (Amora 1973: 178-9).

A primeira decorre entre 1572 (edição comentada pelo Censor Inquisitorial Frei Bartolomeu Ferreira) e 1825, caracterizando-se pela análise do valor d'Os $\mathrm{Lu}$ síadas relativamente a outros ${ }^{2}$. Em termos de crítica literária, subdivide-se em duas fases: 1572 - 1746, com a divulgação do poema através de edições comentadas, das quais se destacam as de Faria e Sousa e João Franco Barreto. A crítica neo-clássica (Willis, 1972), que procedeu à revisão dos trabalhos anteriores e foi marcada por uma leitura ao carácter literário do poema, tanto em Portugal como em outros países, antecedeu o que pode chamar-se de leitura romântica d'Os Lusíadas.

A publicação de Camões, de Almeida Garrett (1825), marca o início da segunda fase, em que as atenções se viraram para o significado do poema enquanto ícon de expressão nacional(ista) ${ }^{3}$ e para a análise da realidade histórica subjacente. $\mathrm{O}$ que equivale a dizer que LC foi, neste período, tido como um representante do ideal Romântico. Este entusiasmo prolongou-se até à celebração do terceiro centenário da publicação d' $O s$ Lusíadas (1872), altura em que se impôs o Realismo

2. «Reduzindo ao essencial a crítica feita ao poema, neste período, poderíamos dizer que, então, se estabeleceu que Os Lusíadas eram (ou não eram) o mais perfeito modelo de poema heróico, portanto superior (ou inferior) aos modelos antigos e modernos desse géneros (...)» (Amora, 1973: 178). No final do artigo (p. 206), num espaço reservado às críticas de outros autores, Arnaldo Saraiva nota que Amora assinalou, não sem razão, que um poema como o de Garrett pode também ser considerado como uma crítica (entendida por Amora ao longo deste trabalho como «juízo de valor»).

3. 10 de Junho é, por isso, dia de manifestações explícitas ou encobertas de (desadequados) movimentos nacionalistas e xenófobos que provocam desalento ao autor destas linhas, que espera que esse dia assinale, para todas e todos sem excepção, uma reflexão sobre a igualdade e sobre o país que temos e para onde queremos leválo. Se para o caminho que agora se vai traçando, se para um outro, alternativo. 
e se iniciou uma fase de mais ampla divulgação da bibliografia passiva e activa do poema camoniano. Ou seja, do valor nacional promovido pelo Romantismo, LC passou a ser tomado como um valor universal, motivando estudos mais sistemáticos sobre a sua vida e sobre a documentação disponível para a interpretação do poema. Aos estudos que incidiram sobre «a linguagem, o conteúdo de saber e particularmente o conteúdo de ideias e sentimentos» (Amora, 1973: 179), acrescentaram-se outros que analisaram vários documentos para definir o percurso de vida do poeta (Storck, 1890, apud Amora, 1980: 10).

Paralelamente, introduz-se o estudo da geografia na crítica do poema camoniano. Em 1883, A.C. Borges de Figueiredo publica uma Carta da Geographia dos Lusiadas de Luis de Camões (1883b), acompanhada por uma nota explicativa (1883a), onde afirma que a sua obra era a primeira dedicada a esta questão (1883a: VI - VII). Este autor procurou, dentro das informações dispersas pela Epopeia, as "raízes" da concepção geográfica camoniana, concluindo, por exemplo, que LC, «á primeira vista, se afferou muito á cosmographia de Ptolemeu, desprezando a teoria de Kopernico» (1883a: 11) .

A análise da realidade contemporânea do poeta, bem como a realização de estudos biográficos e bibliográficos, de tendência historicista, foram dois aspectos criticados por uma nova vaga crítica a partir de finais do século XIX, que se prolongou até aos Anos 30 da centúria seguinte 5 . Neste contexto, destacam-se nomes como José Maria Rodrigues (1905) ${ }^{6}$, Carolina Michaelis, Epifânio da Silva Dias, entre outros (cf. Amora, 1980: 11 - 12), que procuraram resolver os «mistérios da biografia do poeta» e analisar alguns «pormenores da obra», sobressaindo o estudo das fontes do poema camoniano. Em termos de juízo de valor, como apontou Amora (1973), esta tendência analítica não se diferencia muito do programa anterior, mas foi suficientemente assinalável, ao ponto de conduzir à inauguração, na Faculdade de Letras de Lisboa (por Epifânio S. Dias)

4. Manteve-se a ortografia original. Apesar desta novidade em termos de estudos, complementada, anos mais tarde, por Luciano Pereira da Silva (pertencente à fase seguinte dos estudos camonianos), numa obra intitulada Astronomia dos Lusiadas, publicada em 1913 1915 e reeditada pela Junta de Investigações do Ultramar em 1972, o primeiro a integrar LC no contexto da Geografia foi o próprio fundador desta ciência: Alexander Von Humboldt (Ribeiro, 1980: 153 - 7). Para levar a efeito o seu trabalho, Borges de Figueiredo analisou com maior atenção o Canto III, especialmente, 6 - 20, por Vasco da Gama, bem como o Canto X $(79-89)$.

5. Estes estudos foram marcados pelo simbolismo, nacionalismo e espiritualismo.

6. Consultou-se a edição fac-similada da obra, publicada em 1979, correspondendo sempre à referência de Rodrigues, 1905.

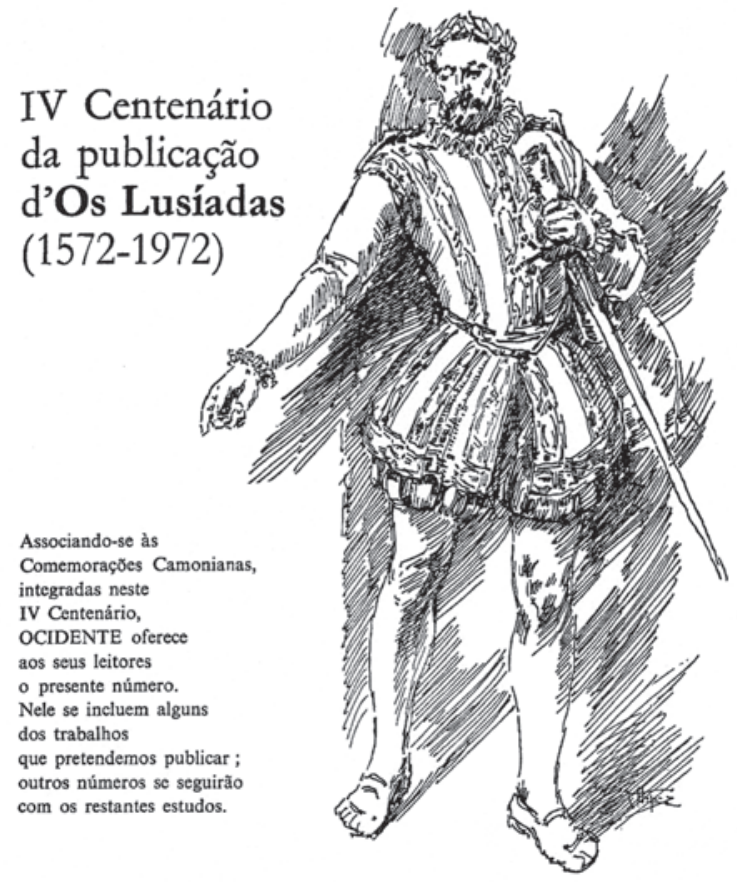

Figura 1. Revista Ocidente (1972)

de uma disciplina dedicada, exclusivamente, aos estudos camonianos, logo ocupada por J. M. ${ }^{a}$ Rodrigues, no âmbito das celebrações do nascimento do poeta, em 1924 (Amora, 1980: 12).

Hernâni Cidade foi discípulo de Rodrigues (cf. Cidade, 1942), ocupando, entre 1932 e 1934, o cargo deixado vago por aquele nos «Estudos Camonianos». Esta mudança conduziu a uma reformulação do pensamento que marcou o início da terceira fase. A prioridade passou a ser a análise dos «valores especificamente artísticos de sua forma e de seu conteúdo» (Cidade, 1951, apud Amora, 1973: 179; 1980: 14), destacando o poeta enquanto agente recriador.

Esta tendência marcou a realização de vários Congressos Internacionais de Camonistas a partir da celebração do quarto Centenário da publicação d'Os Lusíadas (Carvalho e Silva, 1984: 649 - 651), que trouxeram como novidade a revisão da história da crítica textual, bem como a introdução de novas fontes (R. Bismut, apud Carvalho e Silva, 1984: 652) e uma análise sistemática da «herança clássica» na poesia camoniana e no Renascimento Português ${ }^{7}$. A análise dessa «herança»

7. Parte desta bibliografia é apresentada no ponto V («Fontes de inspiração ou superação»). Deve ser complementada com a nossa edição online da bibliografia recolhida, onde se assinalam, por 
é incontornável neste estudo, merecendo, por isso, um breve apontamento ao conceito de «clássico».

Este adquire três vertentes diferentes na língua latina. A reforma censitária atribuída a Sérvio Túlio colocava o classicus na primeira das cinco classes de Roma, ordenadas consoante a riqueza individual. Na escola, era classicus o autor «lido e estudado», o que antecede o conceito estético do Classicismo Helenístico proposto no Cânone de Alexandria: o de classicus scriptor, ou autor destacado pelos seus dotes na utilização da língua materna, orientado para a perfeição. O sentido hoje aplicado de classicus parece surgir pela primeira vez, segundo Curtius (1957, apud Aguiar e Silva, 1962: 4), em 1548, por Thomas Sibillet na obra Arte poétique François, prolongando-se ao longo do século XVIII, com o sentido de autor excelente e estudado ${ }^{8}$.

O termo «clássico» é utilizado neste trabalho como uma convenção conceptual, onde se enquadra a mole heterogénea de autores da Antiguidade Greco-latina que está, eventualmente, presente no poema camoniano. Não se trata de julgar a qualidade das obras que serão aqui focadas, mas antes de tentar perceber que informações bebidas, directa ou indirectamente, destes autores, podem contribuir para a construção do poema e da sua originalidade. Em particular, de tentar procurar compreender como LC olhou e recebeu esses discursos, e como os reproduziu, recriando-os, no seu. E como, neste, introduziu Tartessos.

As estrofes que abrem este texto inserem-se no discurso histórico de Vasco da Gama ao Rei de Melinde (III, 100) e na descrição das bandeiras por Paulo da Gama ao Catual de Calecute (VIII, 29).

Sugerida pela Professora Ana Arruda, esta análise coloca, à partida, dois problemas.

exemplo, estudos que se desenvolveram em torno da relação entre Os Lusíadas e o Antigo Testamento. Veja-se o comentário de Ramalho, 1971 - 1972 à organização de um Curso de Férias em Coimbra (1972), dedicado à tradição clássica. Igualmente incontornável é o magnífico trabalho de Luís de Sousa Rebelo (1980).

8. O «clássico» passa a ser um conceito de referência nos estudos literários com Mme. De Stäel e Goethe, que lhe dão uma conotação estética em comparação com a literatura Romântica. Mme. De Stäel, em De l'Allemagne substitui as designações opostas de Literaturas do Meio-dia e Literaturas do Norte por Poesia Clássica e Poesia Romântica, do mesmo modo que Goethe, considerado como o "fundador" do Romantismo (Bernal, 1993: 207) e como representante de um Helenismo renovado que rompera com o anterior Humanismo latino (R. Pfeiffer, apud Bernal, 1993: 206). Goethe é herdeiro dos trabalhos do Setecentista Winckelmann, que foi o primeiro a separar os conceitos «Gregos» e «Romanos» na sua História da Arte, de 1764, que tinham sido unificados por Cícero e que evitaram a classificação de «bárbaro» por parte dos Gregos em relação ao Latim (Pereira, 2007a: 76 - 7). Remeto a leitora ou o leitor para o notável e exaustivo estudo de V. Aguiar e Silva (1962).
O primeiro diz respeito aos significados que o termo tem nestes versos. No caso de III, 100. 8, LC refere-se aos «campos tartésios» e em VIII, 29,8, a um rio. Esta diferenciação indica, pelo menos, várias proveniências distintas, entre as quais, pelo menos, Pompónio Mela, Plínio e Estrabão, assinalados pelo poeta no episódio do Adamastor (V, 50).

O segundo é subsidiário do primeiro. As bases do poema camoniano não parecem esgotar-se no mundo greco-latino, estendendo-se a outros autores portugueses (Garcia de Resende, Rui de Pina, João de Barros, etc.), espanhóis (entre outros, Juan de Mena e, provavelmente, como veremos, Antonio de Nebrija e Pedro de Medina) e até mesmo italianos. Por exemplo, tanto Afrânio Peixoto (1932) como Hernâni Cidade (1981: 121 e 132) apontam que J.M. ${ }^{a}$ Rodrigues (1905) não valoriza o suficiente a presença da influência espanhola nos versos camonianos. Porém, mesmo os autores que se dedicaram a este ramo da intertextualidade d'Os $\mathrm{Lu}$ síadas $^{9}$, incidiram sobre as fontes poéticas na Lírica e na Épica camoniana, deixando de lado outras obras de índole historiográfica produzidas no outro lado da fronteira e que, ao que sabemos, foram valorizadas por Epifânio Dias, ao comentar Lus. III, 17 - 20 (apud Ribeiro, 1971 e Pinho, 2007b: $142-3)^{10}$. Esta análise, note-se, não parece chocar com o interesse camoniano pela Cronística e Historiografia portuguesas.

A análise que apresento incide sobre oito linhas de força: (I) a vida do poeta e a sua inclusão no (II) contexto do Humanismo, que terão influenciado a aprendizagem de LC e, consequentemente, (III) a construção do poema. É aqui que se incluem algumas das (V) «fontes» de LC, a partir das quais é possível explicar a estruturação dos Cantos (VI) III e (VII) VIII, onde surge Tartessos. Dediquei algumas palavras à questão da (VIII) métrica, de modo a procurar justificar a escolha de Campos Tartésios e de Tartesso, respectivamente, em III, 100 e VIII, 29.

É com este quadro de referências, bastante concreto e, ao mesmo tempo, limitado, que vamos debruçar-nos sobre estes dois excertos do poema camoniano, cujos resultados são apresentados no ponto IX: «Tartessos n'Os Lusíadas».

É, portanto, momento de passar para o segundo ponto, mas não sem antes deixar um comentário a este trabalho: o seu verdadeiro valor não está naquilo que

9. Veja-se, para além dos autores já citados, Lemos e Almoyna, s.d.; Dasilva, 1998; Castro, 2004; Extremera Tapia, 2005; de referir também os estudos sobre o bilinguismo Português - Castelhano no século XVI: Lemos e Almoyna, s.d; Vázquez Cuesta, 1981.

10. Consultei uma edição fac-similada da $2^{a}$ edição (1916/ 1918, 2 Vols.) d'Os Lusíadas, com comentários de Epifânio da S. Dias (1972). 
apresenta, mas no uso que dele se faz, e na crítica da leitora ou do leitor. A sua originalidade está na conjugação de informações retiradas de temáticas muito diversas, estudadas e apresentadas por autoras e autores que se debruçaram sobre o apaixonante mundo de LC e da crítica Camoniana.

\section{LUÍS DE CAMÕES (1524/ 1525 - 1580)}

« Tendo vivido quase isolado dos seus pares, nenhum deles em sua vida se lhe refere e só depois da morte mereceu de um ou outro raro amigo uma breve alusão, que na ausência geral delas, atinge valor de preciosa.»

Hernâni Cidade (1984: 136)

«Mas eu que falo, humilde, baixo e rudo/ de vós não conhecido nem sonhado?/ Da boca dos pequenos sei, contudo,/ que o louvour sai às vezes acabado./ Nem me falta na vida honesto estudo,/ com longa experiência misturado,/ nem engenho, que aqui vereis presente,/cousas que juntas se acham raramente.»

Os Lusiadas X, 154

Os elementos disponíveis para a reconstituição de uma biografia de LC são escassos e, não raras vezes, duvidosos.

A começar pelo seu nascimento. Calcula-se que terá nascido em 1524 ou 1525 (Lopes \& Saraiva, 1998: $317)^{11}$, em lugar incerto (Coimbra? Lisboa? Porto?), levando a que não se saiba, com precisão, com que idade terá iniciado os seus estudos em Coimbra. A data desta entrada parece ser posterior a Dezembro de 1539, data limite de um documento identificado, na Torre do Tombo, por Cândido dos Santos, e publicado em 1973, onde não figura o nome de LC (Cruz, 1984).

Por esses anos, D. Bento de Camões, tio do poeta, era Prior de Santa Cruz de Coimbra, o que leva a pensar, juntamente com a escolaridade que parece reflectir-se no poema, na possibilidade de entrada nos cursos de Artes e/ou Gramática (Cruz, 1984: 36). Não devemos, porém, descartar a hipótese de conhecimentos adquiridos na Índia (Ramalho, 1980a: 1-2), atendendo, por exemplo, a X, 154, mas, por outro lado, parece evidente que detinha um excelente conhecimento

11. Faria e Sousa corrigiu a data de 1517 para 1525 , baseandose no registo da Armada de 1550 , onde figura o jovem LC, com a idade declarada de 25 anos. Para um esquema genealógico da família do poeta, veja-se a excelente edição escolar d'Os Lusíadas organizada por Emanuel Paulo Ramos (D.L. 2000). Veja-se, igualmente, Livermore, 1984 e, para o «honesto estudo» de LC, Pereira, 2007b: passim de Latim e, com menos probabilidade, de Grego (Pereira, 2007a: 71 - 3; Ramalho, 1984: 495) ${ }^{12}$. Terá iniciado os seus estudos num período de maior abertura às transformações intelectuais de além - fronteiras, como veremos, o que conduziu ao conhecimento de algumas obras da Antiguidade, acessíveis em textos, originais ou traduzidos, impressos ou manuscritos, ou mesmo coligidos e sistematizados em compêndios, manuais e dicionários.

Seria fastidioso (e, na verdade, inútil) fazer aqui uma exposição detalhada do que se pensa que foi a vida do poeta. Apenas de assinalar uma vida difícil e até mesmo errante durante os seus anos de juventude, depois de 1542, ano em que, provavelmente, deixara Coimbra para ir para Lisboa, onde se estabeleceu até 1545, partindo depois para Ceuta, onde perdeu um olho. Regressado em 1548, no ano seguinte enquadrase na vida cortesã, pelo menos até 16 de Junho de 1552, dia fatídico, que, motivado pela agressão de um funcionário do Paço com uma espada, o levou à Prisão do Tronco. A pena durou até 7 de Março do ano seguinte, depois de uma carta de perdão, não deixando outra alternativa a LC que não a de embarcar para a Índia na nau S. Bento, regressando apenas em 1569, já com a sua epopeia nas mãos. Em 1572, publica Os Lusíadas e morre em 10 de Junho de 1580.

É este, em traços muito gerais, o provável rumo da vida do poeta nas suas andanças pelo mundo. Vejamos agora alguns aspectos do seu ambiente cultural.

\section{O AMBIENTE CULTURAL DE CAMÕES}

O ambiente cultural de LC deve ser visto na perspectiva do Humanismo ${ }^{13}$ e das dificuldades impostas pelo pensamento escolástico (censura), bem como na vida universitária do Portugal Quinhentista.

12. A hipótese de um bom conhecimento de Latim é muito provável, atendendo a vários «latinismos» utilizados pelo poeta na sua obra, aos quais vou referir-me mais adiante. A questão da aprendizagem do Grego levou-me a introduzir, no capítulo das fontes de LC, a discussão em torno da leitura dos originais gregos dos Poemas Homéricos.

13. Para uma discussão sobre o conceito e as suas manifestações, cf. Ribeiro, 1980: 17 - 99, com bibliografia. O termo surge em 1808 com F.J. Nyethamer, «para definir uma concepção pedagógica na qual se dá o primado aos estudos clássicos», acrescentando-se que «por humanista deve entender-se fundamentalmente o estudioso e cultor das artes humanitatis e litterae humaniores, expressões ciceronianas, cujo sentido indica que o conhecimeto dessas letras torna o homem mais humano pelo que elas lhe revelam sobre a sua natureza e condição» (Ribeiro, 1980: 69). Para a relação entre LC e o Humanismo em Portugal, veja-se Ramalho, 1971 - 1972a; 1984; Pina Martins, 1981. 
Silva Dias assinala o confronto entre a Escolástica e o Humanismo no sentido de se tornarem «hegemonias culturais» (1981: 13 - 21, apud Barreto, 2000: 89), em que a primeira procura salvaguardar o domínio no seu rebanho, protegendo-o do segundo. Este aspecto é notório em 1548, ano em que se inicia um domínio humanista do ensino, culminando em 1555, com a entrega do Colégio das Artes à Companhia de Jesus ${ }^{14}$. Assim, «o programa humanista é, ao longo de 1540 - 1560, neutralizado ou integrado na Escolástica» (Barreto 2000: 90).

Entre estas duas hegemonias, surge uma cultura discursiva - a dos Descobrimentos e da Expansão -, um conjunto heterogéneo que reflecte as partes interessadas neste processo: Coroa, Igreja e restante sociedade. Os seus discursos, não pertencendo a nenhuma das hegemonias e, portanto, mais abertos a novas informações, pouco ou nenhum impacto tiveram nos programas de ensino, apesar do interesse das suas observações para a actualização dos conhecimentos de então ${ }^{15}$. Basta, por exemplo, dizer que, à excepção dos Guias Náuticos (de Évora e de Munique), obras de Astronomia náutica, Livros de Marinharia, Roteiros e Diários de Navegação, encontravam-se manuscritas e tinham, portanto, uma circulação muito limitada.

Paralelamente, a Cartografia náutica teve inovações extraordinárias, com consequências directas para o aumento de informações geográficas do mundo extra-europeu, sendo ela mesma uma consequência directa das viagens e da observação das novas terras ${ }^{16}$. A confrontação com o saber antigo torna-se, portanto, um resultado óbvio de um período de profunda transformação, que foi o de LC. O que justifica a dimensão do Homem no seu poema, como muito bem explica Pina Martins: «Exaltando o génio dos Portugueses no seu acto colectivo mais importante para a história do Mundo, Camões exalta implicitamente a capacidade do homem para resolver dificuldades tidas até então como insuperáveis: as do Oceano com os seus segredos e medos, o misterium maris em que $O s$ Lusíadas aparece reduzido à sua dimensão de realidade cognoscível» (1981: XVIII).

14. Veja-se o estudo de Américo Ramalho (1980 - 1981), onde o autor apresenta, com algum pormenor, a vida universitária no período compreendido entre 1548 e 1554 .

15. Assim, os «sistemas de trocas entre os três componentes chave do Renascimento Português tem a ver com o princípio nuclear de cada uma das culturas. A Escolástica e a Humanista são culturas de orientação sapiencial - doutrinária enquanto que a cultura da Expansão apresenta uma orientação científico - objectiva» (Barreto, 2000 93). Este artigo representa uma interessante reflexão, sustentada por uma bibliografia sólida, sobre a dimensão filosófica destas três culturas discursivas, bem como sobre as diferenças existentes entre elas.

16. Volto a remeter para Barreto, 2000: 102ss, onde o autor apresenta bibliografia sobre este tema.
«O campo doutrinário - ideológico é o lugar do encontro e da transição entre a cultura da expansão e as culturas humanista, escolástica e popular sobre a expansão» (Barreto, 2000: 111). É neste contexto que começam a surgir discursos dominados por três orientações distintas (Dispersão, Autorização e Concentração), caracterizados pelas suas diferentes posições em relação ao processo que LC, em parte, descreve e exalta.

A Dispersão representa uma postura crítica face ao Mercantilismo e à decadência que a Expansão pode provocar para o País. A Historiografia e os discursos políticos e jurídicos surgem como formas de Autorização da Expansão. Na Historiografia, por exemplo, a prioridade é, claramente, dada à diáspora e à sua história $^{17}$, servindo, posteriormente, de base para afirmar a sua grandeza face ao Imperium de Roma (1581, na primeira História de Portugal, da autoria de Fernando Oliveira: apud Barreto, 2000: 111). Como expressão da Concentração surge, entre outras, a obra que motivou esta investigação, uma vez que nela se apresenta e valoriza o sentido da Expansão, ao mesmo tempo que enquadra, como veremos a seu tempo, a viagem de Vasco da Gama num processo histórico iniciado com Luso.

O ensino universitário resume, na perfeição, a luta entre estas hegemonias culturais (Dias, 1981: 13 - 35; Barreto, 2000: passim). As Universidades mantiveramse agarradas ao espírito "medieval" desde 1377, ano em que D. Fernando funda uma em Lisboa. Mais tarde, nos meados de Quatrocentos, D. Pedro procura, sem sucesso, fundar uma Universidade em Coimbra, seguindo os modelos de Paris e Oxford. O «piscar de olhos» a outras tendências de finais do século XV deu-se apenas em 1501. «É então que - à revelia da autoridade universitária - se condimenta o medievalíssimo texto gramatical de João Pastrana com alguns elementos extraídos do renascentista Élio António Nebrija» (Dias, 1981: 30. O sublinhado é meu).

Este último nome é de extrema importância para este trabalho, e tanto mais o é que, em 1525, durante o reinado de D. João III, a Universidade deu abertura aos seus docentes para optar pela sua obra. É um período em que este Rei procurou estabelecer uma reforma no ensino, apesar da resistência por parte do meio universitário lisboeta. Com isto, a solução encontrada foi a fundação de uma Universidade em Coimbra no ano de 1536, recorrendo ao convite de professores nacionais e estrangeiros.

17. Neste contexto figuram nomes como Gomes Eanes de $\mathrm{Zu}-$ rara (c. 1410 - 1474), Gaspar Correia (c. 1490 - c. 1563), Fernão Lopes de Castanheda (c. 1514 - 1559), João de Barros (1496 - 1570), Damião de Góis (1502 - 1574) e Diogo do Couto (1542 - 1516). 
Este panorama permite pensar que foi num ambiente renovador (entre 1536 e 1555) e de entusiasmo generalizado pela Expansão (Matos, 1983: 5 - 11) que se integra parte da vida estudantil do poeta, o que se reflectiu, como continuaremos a ver, numa verdadeira epopeia (humanista) portuguesa.

\section{OS LUSÍADAS: ALGUNS ASPECTOS}

«Vistes que com grandíssima ousadia/ foram já cometer o céu supremo;/ vistes aquela insana fantasia/ de tentarem o mar com vela e remo;/ vistes e ainda vemos cada dia/ soberbas e insolências tais, que temo/ que do mar e do céu em poucos anos/venham deuses a ser, e nós humanos»

Os Lusíadas VI, $29^{18}$

«Ora, n’Os Lusíadas, a descoberta não é apenas a motivação do poeta (...), mas também e principalmente a matéria - prima do poema» (Matos, 1983: 8).

O tema central d'Os Lusíadas é a viagem de Vasco da Gama à Índia, inserindo-a na História de Portugal. Nesta introduzem-se elementos como a concepção da Geografia do seu tempo, os conhecimentos da sua sociedade contemporânea, a História de Portugal e da Antiguidade, Mitologia e Literatura Clássicas, etc. Estes elementos vão de encontro ao seu principal objectivo: engrandecer, preservando, os feitos dos Portugueses através de um discurso poético e, ao mesmo tempo, histórico. Transmitindo a História num discurso épico ${ }^{19}$, o poeta realiza um sonho de gerações anteriores: imortalizar os feitos portugueses, ao mesmo tempo que revela a superação dos autores e modelos antigos através da Epopeia, considerada, não sem razão, como a maior aspiração da poesia ${ }^{20}$.

\footnotetext{
18. Apud Matos, 1983: 8.
}

19. Note-se, por exemplo, que Epifânio da Silva Dias assinalou que a tempestade enfrentada pelas naus comandadas por Vasco da Gama era pura ficção, baseando-se em Castanheda, enquanto que Saraiva afirma, pelo contrário, que se tratou apenas de uma transposição de uma etapa para outra (apud Oliveira, 1998: 417). Ou seja, estes episódios ganham um carácter literário, uma vez que o poeta cria mais um obstáculo que se localiza próximo da concretização do objectivo.

20. Para a discussão sobre a origem da épica grega, veja-se o interessante artigo de M.L. West (1988) e, mais recentemente, a sín-

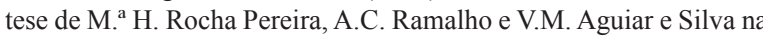
Enciclopédia Verbo (1999: Cols. 487 - 496), onde se expõem as várias manifestações deste estilo na Grécia, em Roma, nas Idades Média, Moderna e Contemporânea. Há que assinalar que a definição moderna de géneros literários iniciou-se depois de 1945, retomando, em parte, o que Quintiliano já havia assinalado quando distinguiu quatro géneros literários (Inst. Orat. X): Poesia, História, Eloquência e Filosofia (Chassignet, 1998: 155). Veja-se, para uma análise estilística da épica latina, Biville e Dangel, 1997: passim.
O Canto I lança a narrativa quando as naus já se encontram no Oceano Índico $(19)^{21}$ e coloca-a em simultâneo com o Consílio dos deuses $(20-41)^{22}$. Este episódio marca um interregno na sequência da viagem: na estrofe 42, os navegantes encontram-se «Já lá da banda do Austro e do Oriente,/ entre a costa etiópica e a famosa/ Ilha de São Lourenço (...)» e encaminham-se para Mombaça, onde se prepara uma traição (105). A última estância, pode dizer-se, é a reflexão que o poeta faz sobre o «bicho da terra tão pequeno» (ou sobre a condição humana) e que retoma nos Cantos IV (Velho do Restelo), V (Adamastor) e no VI (Tempestade).

Esta fase antecede a viagem de Mombaça até Melinde no Canto II, onde o Rei pretende ouvir a História de Portugal, que culmina na partida das naus e no Velho do Restelo. É nesta fase que se dá a primeira intervenção divina, que dá conta da função de intermediários e agentes das forças naturais entre o Homem e Deus. Chegados a Melinde, os navegantes parecem querer seduzir o seu ajudante no sentido de procurarem ajuda para concretizar o seu objectivo ${ }^{23}$. Isto antecede o discurso do Gama ao Rei de Melinde nos dois Cantos seguintes. O Canto V, por sua vez, encerra um ciclo: relata a viagem entre Lisboa e Melinde, colocando no percurso histórico a missão de Vasco da Gama.

A História de Portugal, narrada nos Cantos III e IV, abarca o período compreendido entre Luso e os anos de 1561 - 1562 (Sena, 1980, apud Oliveira, 1998: 409) ${ }^{24}$. Tal percurso temporal parece ser apresentado como

21. Para trás ficaram a proposição (1-3), a invocação (4-5) e a dedicatória $(6-18)$. De acordo com a expressão de Horácio na sua Arte poética (148 - 149), a narrativa é lançada in media res: «semper ad euentum festinat et in medias res/ non secus ac notas auditorem rapit (...)» ou, traduzido: «Sempre se apressa para o desfecho e arrebata o auditor para o meio da intriga como se esta já lhe fosse conhecida» (trad. Pinho, 2007a: 122, n. 169). Em http://www.thelatinlibrary.com/horace/arspoet.shtml encontra-se uma versão online do texto latino (cons. 5/10/09). O lançamento da narrativa d'Os Lusíadas, pode dizer-se, dá-se in extrema res, ou seja, inicia-se quase em Melinde, na última etapa da viagem.

22. Sigo neste trabalho a proposta de Salgado Júnior, seguida por Sena, que utiliza o sentido de consilium identificado na edição princeps d'Os Lusíadas, em alternativa a concilium. Diz Sena que «não se trata de uma mera questão ortográfica. Se é certo que os deuses olímpicos poderiam ser bispos e cardeais da "igreja mitológica", reunidos em concílio presidido pelo Papa (Júpiter), mais certo será que apenas se reúnam em "consílio" (conselho), para decidirem sobre as coisas do Oriente» (1980: 131 e n.4).

23. Para o enquadramento deste episódio-tipo na narrativa, vejase o excelente trabalho de Claude Bremond (1966).

24. Estes acontecimentos, note-se, são posteriores aos que são narrados e, como tal, são apresentados na profecia de Tétis a Vasco da Gama e representam o período contemporâneo do poeta. Veremos mais adiante que este percurso histórico, iniciado com Luso, não recua à chegada de Jafet e do seu filho Tubal à Península Ibérica, como em Pedro de Medina ou noutros historiadores espanhóis. 
Tabela 1: Distribuição das intervenções do poeta e temas da sua epopeia (segundo Sena, 1980).

\begin{tabular}{|c|c|c|c|c|c|}
\hline Cantos & Poeta & Viagem & Deuses & História de Portugal & totais \\
\hline I & 20 & 52 & 34 & - & 106 \\
\hline II & - & 82 & 31 & - & 113 \\
\hline III & 2 & - & - & 141 & 143 \\
\hline IV & - & - & - & 104 & 104 \\
\hline V & 9 & 91 & - & - & 100 \\
\hline VI & 5 & 55 & 39 & - & 99 \\
\hline VII & 24 & 63 & - & - & 87 \\
\hline VIII & 3 & 92 & 4 & - & 99 \\
\hline IX & 7 & 18 & 70 & - & 95 \\
\hline X & 14 & 2 & 140 & - & 156 \\
\hline Somas & 84 & 455 & 318 & 245 & 1102 \\
\hline$\%$ & 8 & 41 & 29 & 22 & 100 \\
\hline
\end{tabular}

uma unidade na qual se destaca um sentido missionário de luta contra os Mouros e, com menor incidência, de luta contra a Nobreza Castelhana ${ }^{25}$. Estes aspectos, estudados por Paulo Oliveira (1998) na relação que faz entre a Literatura e a História no poema camoniano, permitem destacar o valor da Expansão marítima enquanto acto missionário de expansão da Fé. Ou seja: é a continuação da Cruzada ${ }^{26}$. Das 244 estrofes dedicadas ao percurso histórico dos Portugueses, a maioria é dedicada à Guerra Santa (Oliveira, 1998: 411 - 3). O que importa destacar neste capítulo é a passagem por Me-

25. Este aspecto adquire uma forma interessante nas traduções para Castelhano, em que os tradutores chegaram mesmo a alterar o sentido de alguns versos, de modo a dar uma visão mais favorecida da representação camoniana. Tal é o caso de duas traduções de 1580, uma de Benito Caldera (imp. Alcalá de Henares) e outra de Luís Gómez de Tapia (imp. Salamanca), patrocinadas pelas respectivas universidades. Estas traduções são analisadas em pormenor por Nicolás Extremera Tapia (1998), pelo que vou apontar alguns casos expostos pelo autor: LC, em III, 34. 1, diz «Eis que se ajunta o soberbo Castelhano»: Caldera traduz como «Veis que se junta luego el Castellano». Em III, 99.1: «Este sempre as soberbas castelhanas»; «Éste las amenazas castellanas» (Caldera), «Despreciador de fuerzas castellanas» (Tapia). Estes casos multiplicam-se também na tradução de Henrique Garcés, publicada em 1591. Será apenas em 1818 que surgirá uma tradução com novos parâmetros, mais concordantes com o ideal Romântico, em Espanha, da autoria de Lamberto Gil.

26. Assim, logo na segunda estância do Canto I, o poeta afirma que «E também as memórias gloriosas/ daqueles reis que foram dilatando/ a Fé, o Império, e as terras viciosas/ de África e Ásia andaram devastando». linde enquanto episódio estruturante da construção da epopeia: é onde o presente da viagem (iniciada, na narrativa, em I, 19) se encontra com o passado (IV - V).

O segundo ciclo do poema, iniciado no Canto VI, diz já respeito ao presente da viagem e ao seu desenvolvimento até à conclusão. Vejamos como se dividem as intervenções do poeta e os temas ao longo do percurso narrativo (tabela 1), de modo a sintetizar a sua distribuição na epopeia.

Outro tanto pode ser dito sobre o título -Lusíadas -, que identifica os portugueses como descendentes de Luso, filho de Baco. Trata-se de um neologismo, cuja criação foi reivindicada por André de Resende em Carmen eruditum et elegans Angeli Andreae Resendii Lusitani, adversus stolidos politioris litteraturae oblatratores, impresso em Basileia (1531) por Froben. Numa nota ao poema Vincentius levita et martyr (1545), o autor assinala, em duas ocasiões (II, 24 e 48), a origem mitológica do termo, baseando-se em Plínio (Nat. III, 8) ${ }^{27}$, bem como

27. «In universam Hispaniam M. Varro pervenisse Hiberos et Persas et Phoenicas Celtasque et Poenos tradit. Lusum enim Liberi patris aut lyssam cum eo bacchantium nomen dedisse Lusitaniae et Pana praefectum eius universae». Tradução de Amílcar Guerra (1995: 29): «Refere Marco Varrão que à Hispânia em geral chegaram Iberos, Persas, Fenícios, Celtas e Púnicos; que os mistérios (lusus) de Liber Pater ou o delírio (lyssa) das Bacantes com ele deram o nome à Lusitânia e Pã, seu prefeito, a toda ela». N'Os Lusíadas, LC cita, por três vezes, esta personagem (III, 21, VIII, 2 e 3: cf. infra). O texto de Resende é também citado por H.H. Post (1972: 293). 
a filológica, recorrendo a Lucrécio ${ }^{28}$. Já no século XX (1933), Alfredo Pimenta descobre, na Torre do Tombo, Antiquarum Lectonium Libri XVI, de Rhodiginus, publicado em 1516, identificando Lusiades nymphae, onde o autor assinala uma passagem do grego (do século III)

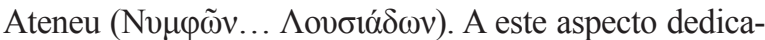
ram-se, posteriormente, Bernardo Xavier Coutinho e J. M. ${ }^{a}$ Rodrigues (Ramalho, 1980b: 221 - 236) ${ }^{29}$.

Esta palavra adquire um sentido identitário, distinguindo os «filhos de Luso» daqueles que não o são, aplicando-se, por exemplo, à diferenciação Portugueses/Espanhóis afirmada por LC. Esta identificação esbate-se quando o inimigo comum é o «Mouro» e há uma afirmação da Cristandade ${ }^{30}$, levando a questionar as várias transformações que a Identidade pode ter numa mesma sociedade, ou no mesmo «Eu». A identificação de Portugal com a Lusitânia parece surgir em 1481 numa oração de D. Garcia de Meneses (Bispo de Évora), ganhando consistência a partir da conquista de Granada em 1492 (Ramalho, 1984: 492).

Estas diferenças são, igualmente, fundamentais na comparação entre o que foi feito na Historiografia Portuguesa e na Espanhola no século XVI, enquanto construções de Identidades. Estes discursos têm em comum a pesquisa de textos antigos, interpretados no sentido de definir as "raízes" destas civilizações europeias, por isso vale a pena entrar, agora, no capítulo das «fontes» d'Os Lusíadas.

\section{V. «FONTES» DE INSPIRAÇÃO OU SUPERAÇÃO}

«É que a poesia, sendo arte autêntica, é vida transposta na dignidade da palavra, e a palavra valiosa não se compraz com exercícios puramente teoréticos. Ela é um produto do humano; é tempo; é história: o seu presente só é explicável pelo seu passado

28. «Aeneadum genetrix, hominum divomque voluptas,/ alma Venus, caeli subter labentia signa/ quae mare navigerum, quae terras frugiferentis/ concelebras, per te quoniam genus omne animantum/ concipitur visitque exortum lumina solis (De Rerum Natura I, 1-5). O excerto faz parte de uma invocação a Vénus, e é traduzido por Alfred Ernout (1966) deste modo: «Mère de las Énéades, plaisir nus nourricière, toi par qui sous les signes errants du ciel, sons se peuplent de créatures, puisque c'est à toi que toute espèce vivante doit être conçue et de voir, une fois sortie des tenèbrees, la lumière du soleil (...).

http://www.thelatinlibrary.com/lucretius/lucretius1.shtml, consultado a 16 de Outubro de 2009.

29. Remeto para o artigo de Ramalho publicado nesta obra, intitulado "A palavra Lusíadas», onde apresenta uma excelente síntese desta discussão. Do mesmo autor, veja-se o artigo publicado em 1984

30. Esta questão é notória no episódio da batalha do Salado (III, $99-117)$ e o seu futuro só será explicável pelo seu presente. O problema das fontes é (...) um problema fundamental ao nível de toda e qualquer pesquisa crítica que aspire a ser rigorosa e exacta».

J.V. de Pina Martins (1972: 199)

Nestas palavras, entrevê-se uma necessidade premente: procurar entender, no contexto de elaboração d'Os Lusíadas, os textos ou os conhecimentos que LC pode ter presentes, não excluindo, claro, situações que podem resultar de coincidências. Torna-se essencial dividir a análise em três grupos: (1) os «clássicos»" (2) os autores portugueses e (3) os autores espanhóis, cada qual com o seu peso no poema. Desta apresentação não sai -convém salientar - uma resenha de todas as fontes de LC, o que está fora do alcance de um único trabalho ${ }^{32}$.

«Cessem do sábio Grego e do Troiano/ as navegações grandes que fizeram;/ cale-se de Alexandre e de Trajano/ a fama das vitórias que tiveram; que eu canto o peito ilustre Lusitano,/ a quem Neptuno e Marte obedeceram./ Cesse tudo o que a musa antiga canta,/ que outro valor mais alto se alevanta.»

Os Lusiadas I, 3

É tradição anterior a LC a comparação entre Portugueses e «clássicos»" ${ }^{33}$, aqui utilizada no sentido de superação nas Letras, na História e na Memória póstuma $^{34}$. O uso de cessar e calar (em latim, cedat e taceat) parece resumir a postura do poeta perante es-

31. Não se justifica, neste contexto, separar Gregos de Romanos, uma vez que esta separação resulta dos estudos de Winkelmann, no século XVIII, sobre a Arte da Antiguidade. O que quer dizer que Camões entendia estas duas realidades como uma só, da qual se consideraria, eventualmente, um herdeiro.

32. Como afirma Luís de Albuquerque (1981: 35): «Il est évident que l'immense acquis culturel de Camões permettra dificillement à quelqu'un d'oser un jour indiquer, même avec une probabilité minime, tous les livres qu'il peut avoir lus. La question, posé ainsi en termes aussi généraux, cesse, à mon avis, d'avoir quelque sens. Cependant elle en aura déjà un si nous extrayons tel ou tel passage très concret et nous en cherchons l'origine; dans ce cas nous pouvons trouver très souvent dans la littérature existant à son époque la source ou les sources où le Poète trouva l'information dont il manquait» (o sublinhado é do autor).

33. Esta tendência, nota Pereira (2007a: 63) vem já do Cancioneiro Geral, de Garcia de Resende. Para a relação entre este texto e o poema camoniano, veja-se, igualmente, Miller, 1972: passim.

34. Sistematicamente (IV, 5; IV, 20; III, 131; III, 133; III, 136), LC revela «a preocupação de fornecer contrapartidas romanas aos heróis e feitos portugueses» (Pereira, 2007a: 74). Note-se que este herói colectivo opõe-se ao herói individual dos épicos antigos. Cataldo Sículo escreveu a D. Manuel uma carta onde expõe uma comparação entre a celebração de Eneias (que viajou da Frígia para Itália) e os antepassados do rei, que «com maior frequência, passaram contra os mouros em África, apesar de dois inimigos que se opunham, a saber, 
tes «inspiradores», o que é definido por Curtius como Überbietung ou esquema de superação (1948, apud Pereira, 2007a: 61-2). Baseando-se, provavelmente, em expressões de Estácio (Curtius, 1969, apud Flasche, 1973: 156) e Propércio (Flasche, 1973: 156), LC assinala esta superação no campo literário (Odisseu/Ulisses e Eneias) e histórico (Alexandre e Trajano), parecendo afirmar os Portugueses como continuadores naturais da Antiguidade Clássica ${ }^{35}$.

O conhecimento de Homero, Virgílio, Valério Flaco, Ovídio, Estrabão, Mela, Lívio, Ptolemeu, Plínio e alguns outros mais parece revelar-se, implícita ou explicitamente, n'Os Lusíadas, obrigando a uma necessária intertextualidade que permita compreender a importância de cada um destes autores na criação poética ${ }^{36}$. Impõem-se, neste panorama, algumas exclusões, começando pelos épicos citados, uma vez que não apresentam uma relação directa com Tartessos ${ }^{37}$. Sobressaem, naturalmente, Estrabão, Plínio e Mela, pese ainda a possibilidade de recepção indirecta destas obras. No entanto, vale a pena abordar ao de leve os poetas épicos, pois permitem questionar, por exemplo, a noção de imitatio, que merece uma breve reflexão.

A imitação (= mimesis) foi discutida, primeiramente, nas obras de Platão (República e Timeu): «se as ideias puras é que constituem a exemplaridade autêntica de todas as coisas, então, o existente concreto não pode ser mais do que imitação (ou semelhança,

a distância e o mar, e sem que alguma vez príncipe cristão os auxiliasse» (apud Ramalho, 1980a: 7).

Aqui faria todo o sentido introduzir a expressão de João de Barros, imortalizada no Prólogo da Década I (publicada em 1552), para assinalar esta questão como uma preocupação mais alargada: «(...) E vendo eu que, nesta diligência e encomendar as coisas à custódia das Letras, conservadoras de todas as obras, a nação portuguesa é tão descuidada de si quão pronta e diligente em os feitos que lhe competem por milícia, e que mais se preza de fazer que de dizer (...)» (apud Ferreira, 1998: 202).

35. Ou, mais adiante, em I, 24: «Como é dos fados grandes certo intento/ que por ela se esqueçam os humanos/ de Assírios, Persas, Gregos e Romanos» (apud Gonçalves, 1950 - 1951: 277). Junte-se a isto a preponderância que LC atribui a Lisboa na História de Portugal, uma vez que, em VI, 7 afirma: «Via estar todo o Céu determinado/ de fazer de Lisboa nova Roma» (cf. Castelo - Branco, 1982).

36. O peso de Ptolomeu, por exemplo é notório na elaboração da «máquina do mundo» revelada ao Gama no Canto X. Para um exame mais completo deste tema, cf. o trabalho de M. ${ }^{\mathrm{a}}$ Helena da Rocha Pereira (2007a: passim) e o primeiro capítulo dos Estudos Camonianos, de A.C. Ramalho. Para o tema específico de Ptolomeu, veja-se o artigo de J.D. Lourenço (1999).

37. Indirectamente, porém, é possível. Odisseia, por exemplo, apresenta três tipos de paisagem limítrofe: escatológica (Elysion), humana (Esquéria) e Monstruosa (Cíclopes), que podem ser transpostas, eventualmente, para a descrição de Tartessos (Albuquerque, 2008). Não considero sequer esta hipótese, uma vez que interessa verificar qual a recepção destes textos em LC e não na minha sensibilidade. omoiosis) mais ou menos afastada, dos arquétipos primordiais» (Mendes, 1999: col. 555). Ou seja, no sentido filosófico de Platão, o mundo sensível mais não seria que uma mimesis do mundo das ideias (Pires, 1999: Col. 556). Aristóteles (Poética), por seu turno, atendeu ao acto de imitar como uma recriação, que por sua vez deveria ser fiel ao objecto que imita (mais concretamente, o Ser Humano e a sua vivência, nas suas virtudes, defeitos e vícios), tal como se verifica na Tragédia e na Comédia (id., ibid).

No mesmo contexto em que surge a noção de classicus scripor, os autores «clássicos» são vistos como os objectos da imitação, visto que são encarados como os representantes por excelência da realidade humana. $\mathrm{Na}$ linha de pensamento aristotélica, essa imitação não deixa de ser vista como uma recriação que deve tender a ser fiel ao objecto a imitar (Mendes, 1999: Col. 556).

Esta discussão acaba por fazer parte dos debates do Renascimento, sobretudo a partir de Petrarca, manifestando a inexistência de uma originalidade absoluta e a tentativa de imitar «la lengua latina en todo su esplendor, en su Edad de Oro», bem como «las virtudes literarias y éticas de los autores clásicos» (Martín Baños, 2006: 288) ${ }^{38}$. Terá sido neste conceito de imitatio que LC foi formado, mas não deixou, tal como muitos dos seus contemporâneos, de procurar a sua originalidade. É nesta linha que J. F. Barreto, partindo de outros comentadores ${ }^{39}$, responde a Pires de Almeida, que «acusara (...) o Épico de ter furtado a ficção onírica do Venturoso do Livro VIII da Eneida» (Castro, in Barreto, ed. 1982: XIII). Esta imitação era, portanto, imprescindível na construção literária, oferecendo-se a um poeta do Renascimento um leque de opções entre vários autores, muitos deles compilados e sistematizados em manuais ou dicionários, dispensando, nalguns casos, a leitura das obras integrais.

38. Lázaro Carreter sintetiza na perfeição esta questão: «La imitación de un solo no pasaría de mero ejercicio escolar; de ahí, la necesidad de acudir a varios que, bien asimilados, transformados y reducidos a unidad, es decir, convertidos al sentimiento personal que impulsa a la escritura, permite no identificarse con ninguno y, si se triunfa en el empeño, obtener un resultado patentemente original» (1980: 95; o sublinhado é do autor). Para J. Lourenço de Carvalho a imitação dos poetas latinos por parte de LC é uma «verdade incontroversa». Por outro lado, afirma que «a originalidade, tal como hoje julgamos entendê-la, era ignorada pelos Antigos e no Renascimento, que prolongava, rejuvenescendo-a, a cultura greco-latina» (1980: 6). Não creio que essa originalidade fosse ignorada, apenas tinha um conceito bem diferente daquele que passou a circular com o Romantismo (veja-se o artigo recente de Martín Baños, 2006). Para as noções de Imitação e originalidade, v. Pires, 1982: 15ss.

39. Jacob Pontano (comentador de Virgílio), Ludovico Dolce (Orlando Furioso, de Ariosto) e D. García de Salcedo y Coronel (Soledades, de Góngora). 
A influência de Virgílio na construção d'Os Lusíadas (Carvalho, 1980; Almeida, 1997: passim; Campos, 1998: $121-3)^{40}$ é um aspecto constatado, pelo menos, desde Faria e Sousa, ao qual foram acrescentadas diversas perspectivas, entre elas o uso de expressões que lembram fórmulas latinas ${ }^{41}$. Um exemplo provém do primeiro verso da epopeia: «As Armas e os Barões assinalados», que pode corresponder ao virgiliano Arma virumque, bem como a possível adaptação de «assinalados» a insignis ${ }^{42}$. Os feitos destes são, naturalmente, comparados com Eneias, como vimos, em afirmação da verdade que o poeta procura atingir.

Esta recepção não é sinónimo de decalque. A adaptação das informações no espírito do agente recriador conduz a diferenças entre os poemas épicos. Uma delas é o início da narrativa, in media res em Eneida e in extrema res n'Os Lusíadas, enquanto que as outras são: o Consílio dos deuses (Canto I d'Os Lusíadas e X, 1 - 117 na

40. A este respeito, Justino M. Almeida assinala que, no Séc. XVII, João Franco Barreto considerou Os Lusíadas como um dúplice de Eneida. Na tradução que fez do poema latino, Barreto utilizou passagens inteiras do poeta português, bem como algum vocabulário. Assinala também que a Expressão «Por mares nunca de antes navegados» é uma reprodução de Prima deum magnis caminus freta per via natis/ Fatidicam que ratem; Scythici quae Phaisidis oras/ Ausa sequi, mediosque inter juga concita cursus/ rumpere, flammifero tandem consendit Olympo, da proposição de Argonáutica de Valério Flaco (Salgado Júnior, 1951: 264; Almeida, 1997: 49-50). Esta é muito diferente da proposição de Apolónio. A influência de Virgílio na epopeia quinhentista, no caso particular da épica espanhola, foi tratada com profundidade por Lara Vilà i Tomàs (2001).

41. Entre estas contam-se (1) latinismos lexicais, (2) latinismos sintácticos, (3) pormenores literários, (4) episódios e (5) factores estruturais básicos. Nestes últimos incluem-se nove: (a) proposição, (b) invocação, (c) dedicatória, (d) narração, (e) discursos, (f) tempestades, (g) intermédios líricos, (h) sonhos e profecias, (i) mitologia. Sigo a ordenação e a terminologia expostas por Carvalho (1980: 10). Remeto para este artigo uma maior pormenorização de paralelismos entre LC e Virgílio, bem como o interessante - e mais recente - estudo de Sebastião Tavares de Pinho (2007a). Este salienta (p. 125ss) o episódio da hospitalidade do Rei de Melinde, infundida por Mercúrio, bem como uma passagem de En. I, 607 - 610 em comparação com Lus. II, 105. 5-8, também valorizada por J.M. de Almeida (1950 1951). Cf., infra, o capítulo intitulado «O Canto III», para a análise da estadia do Gama em Melinde, onde se expõe a História de Portugal e onde surge, pela primeira vez no poema, Tartessos.

42. Arma virumque cano, Troiae qui primus ab oris/ Italiam, fato profugus, Laviniaque venit/ litora, multum ille et terris iactatus et alto/ vi superum saevae memorem Iunonis ob iram (En. I, 1-4 texto online em http://www.thelatinlibrary.com/vergil/aen1.shtml, cons. 5/10/09). Salienta Pinho (2007a: 120) que LC terá optado por «assinalados» devido à métrica, em vez do tetrassílabo insignes. Por outro lado, as vogais parecem, neste verso, adquirir uma grande importância, sobretudo do ponto de vista sonoro do canto. Acrescenta que o substantivo português sinal vem do latim signum e significam, em ambas, «aquele que dá sinal de si, que se mostra acima dos outros, e por isso se torna insigne, notável e primeiro que todos os demais em qualidade, nobreza e valor» (2007a: 121)
Eneida) a distribuição dos opositores (Juno em Eneida e Baco n'Os Lusíadas; v. Ramalho, 1980a: 15-16; Pinho, 2007a: 123) e a introdução de uma nova personagem ajudante - Marte - por parte de LC, que se junta a Vénus. Esta, tal como a Eneias, protege os Portugueses.

A presença de Homero, por seu turno, parece levantar mais questões que a de Virgílio, sobretudo no que toca ao conhecimento de Odisseia. Esta obra pode ter chegado a LC por intermédio de mediação (Lourenço, 2004: 259ss), de leitura do original grego (Pereira, 2007a: 61 - 81; Lourenço, 2004: 260) ou de uma tradução (Alves, 2001: 71; 2005). Daqui surge uma discussão sobre a circulação, a tradução e a acessibilidade destas obras no tempo de LC, ao mesmo tempo que devem considerar-se as condições de execução do poema. Ou seja, entre a leitura do original grego e a de uma tradução, as perguntas multiplicam-se, sem que se saiba ao certo se LC aprendeu esta língua ou não, ou se terá consultado, por exemplo, a edição traduzida e publicada em 1550 por Andrea de Portonatiis (encontrase, actualmente, na biblioteca pública de Évora). A particularidade desta edição é o seu título: De la Ulyxea de Homero. XIII Libros traducidos de Griego en Romance Castellano por Gonzalo Pérez (apud Alves, 2005: 45).

Os conhecimentos de LC sobre Odisseia não parecem ir mais além dos treze primeiros Cantos da obra (idem, ibid.: 45), mais precisamente dos Cantos V e VIII - XIII (Lourenço, 2004: 264): «Camões ignora por completo tudo o que acontece na Odisseia depois da chegada de Ulisses a Ítaca no Canto XIII» e "desperdiça" algumas oportunidades que teve de manifestar erudição ${ }^{43}$. A esta publicação haveria que acrescentar outras que podem ter sido acessíveis (edições de 1524, em Latim; 1528, 1548, em grego, e 1556, em Castelhano). É de salientar também que, por exemplo, em

43. Hélio Alves (2005) não parece responder a alguns argumentos de M. ${ }^{\mathrm{a}}$ H. da Rocha Pereira, expostos no ensaio de 1984 (= 2007a), apesar de citar este estudo. Embora a autora não valorize em excesso estes documentos, vale a pena citá-los: (1) o Grego era uma língua sagrada, a par do Latim e do Hebraico, de acordo com um regimento escolar de Coimbra, datado de 1537; (2) também desse ano, uma carta de Clenardo diz que «Fabrício comentava Homero sem o traduzir de grego para latim, como se estivesse na própria Atenas»); André de Resende ensinava, contudo, o seu pupilo em latim e este conheceu, pelo seu mestre, as obras de Porfírio e Aristóteles (Pereira, 2007a: 72 -73). A crítica daquele autor recai mais sobre o trabalho de Frederico Lourenço (2004). Mesmo não sendo, como aquela autora afirma, decisivos, estes argumentos podem servir como aproximação ao conhecimento da Odisseia por parte de Camões mas, não esqueçamos, o poeta oculta ou desconhece os acontecimentos posteriores ao Canto XIII. Neste sentido, Lourenço assinala como exemplo do Rei Équeto, que arranca narizes em Odisseia, referido no Canto XVIII do Poema Homérico. Pelo contrário, Camões apresenta como paralelo para este acto, em III, 93, Fálaris (Lourenço, 2004: 264). 
II, 82 (cf. infra), LC parece dar a entender que o Rei de Melinde desempenha a mesma função de Alcínoo na Odisseia, isto é, a da personagem ajudante.

Há, contudo, que ter em consideração dois aspectos: o carácter selectivo da recepção e reutilização de qualquer obra e, como veremos a seguir, o objectivo de um discurso e da viagem que o norteia. No discurso de LC, creio que não há grandes motivos para recorrer ao regresso de Odisseu a Ítaca e à vingança dos pretendentes.

Quando saiu de Lisboa, Vasco da Gama tinha por objectivo a chegada à Índia. Interessava mais referir alguns episódios míticos da viagem de Odisseia (Cícones, Lotófagos, Cíclope, Circe, etc.), ou até mesmo utilizar a narrativa da viagem de Odisseu ${ }^{44}$, para superar os seus modelos, comparando-os aos heróis do poema camoniano. Vejamos, então, o que diz o poeta a este respeito em VIII, 88-9 (cf. Pereira, 2007a: 71):

«Cantem, louvem e escrevam sempre extremos/ desses seus semideuses e encareçam,/ fingindo Magas Circes, Polifemos, / Sirenas que c'o canto os adormeçam;/ dêem-lhes mais navegar à vela e remos,/ os Cícones, e a terra onde se esqueçam/ os companheiros, em gostando do loto;/ dêem-lhes perder nas águas o Piloto.

Ventos soltos que lhe finjam e imaginem/ dos odres, e Calipsos namoradas;/ Harpias, que o manjar lhe contaminem; / descer às sombras nuas já passadas./ Que por muito e por muito se afinem,/ nestas fábulas vãs, tão bem sonhadas, / a verdade que eu conto, nua e pura,/ vence toda grandíloca escritura.»

É neste contexto que Salgado Júnior (1950; 1951) e R.M. Rosado Fernandes (1980: 10 - 11) colocam um acento tónico para discutir o pendor das epopeias antigas no poema camoniano. Excluindo a primeira por não se tratar de uma viagem, as restantes três dão a entender que o objectivo dos Portugueses se assemelha mais à busca do Tosão de Ouro (Argonáuticas), não se tratando nem de uma viagem de regresso (Odisseia) nem de uma viagem fundacional (Eneida). Não é apenas no objectivo que as viagens diferem da do Gama. Difere também o tratamento que o poeta lhes dá ao longo do seu projecto. Em duas ocasiões, apresenta os protagonistas como os Argonautas ou como os «segundos Argonautas ${ }^{45}$, o que deve ser comparado, por

44. Comparando, por exemplo, o Canto VI d'Os Lusiadas com o V de Odisseia (Alves, 2001: 486 - 7; 2005: n.6).

45. «E vereis ir cortando o salso argento/ os vossos Argonautas $(\ldots) »(I, 18)$ e, mais adiante, «Nesta frescura tal desembarcavam/ já das naus os segundos Argonautas» (IX, 62). Uma das obras coligidas exemplo, com V, 86: "Crês tu que tanto Eneias e o fecundo/ Ulisses pelo mundo se estendessem?»

Comparando feitos e conhecimentos com os seus inspiradores, LC considera que estas viagens são «fábulas vãs» e afirma, com isto, a sua «verdade (...) nua e pura $»^{46}$, seguindo em boa medida os objectivos do discurso historiográfico português do seu tempo. A viagem simbólica, de regresso ou de fundação, que caracterizou Odisseia e Eneida é, agora, substituída por uma viagem real, sem que, para isso, deixem de estar presentes na sua construção poética alguns aspectos formais (obstáculos e personagens ajudantes, a Ilha dos Amores como recompensa e divinização dos protagonistas, etc. $)^{47}$. Façamos um breve comentário a este aspecto.

Aparentemente, a utilização destas divindades poderia induzir a contradições na construção do poema, centrada no objectivo da «verdade». Uma dessas possíveis contradições é notada por Segurado de Campos num brilhante ensaio (1998) que estuda o «classical background» da poesia épica portuguesa em textos desenvolvidos e produzidos entre os séculos XVI e XVII ${ }^{48}$, no contexto de uma questão fundamental: a presença de divindades dos «Gentios» no poema camoniano, e como foi possível contornar a censura da Inquisição (cf. Anselmo, 1981: passim; Ramalho, 1975, apud Pe-

na Exposição bibliográfica organizada por Pina Martins (1972) inclui o Tosão de Ouro ou, se preferirmos, o Second volume de la Thoyson dor, de extrema importância na formação da Ordem do Tosão de Ouro em Bruges (10 de Janeiro de 1430), que assinalava, pela figura de Jasão, as virtudes cavaleirescas. Jasão foi patrono apenas por um ano. A Ordem, reunida em Lilles em 1431, acabou por eleger Gedeão, uma vez que se aproximava mais da Bíblia (p. 204 - 5). Outra obra é a de Apolónio de Rodes, publicada em 1521 com título em Grego e Latim: Apolonii rhodii Argonautica, antiquis unà, et/ optimis cum commentariis (p. 206 - 7). Veja-se Salgado Júnior, 1950 e 1951, para este tema, sintetizado em Almeida, 1997: 49 - 50.

46. Esta comparação é também evidente no discurso de Vénus em IX, 38 («E porque tanto imitam as antigas/ obras de meus Romanos, me ofereço/ a lhe dar tanta ajuda em quanto posso,/ a quanto se estender o poder nosso») e de Júpiter em II, 44 («Que eu vos prometo, filha, que vejais/ esquecerem-se Gregos e Romanos,/ pelos ilustres feitos que esta gente/ há-de fazer nas partes do Oriente»). (apud Pereira, 2007a: $77-8$ ).

47. Veja-se, a este respeito, Albuquerque, 2008, relativamente ao papel da personagem ajudante que ajuda o protagonista a superar um obstáculo. No caso de Odisseia, Alcínoo desempenha este papel tal como, provavelmente, Argantónio no relato dos Foceenses (Heródoto I, 163). Sobre a função do ajudante, cf. Bremond, 1966, passim. No caso de Camões, não há qualquer interesse em exacerbar as condições de vida de Melinde, daí encontrarmos uma diferença fundamental que tem que ver, essencialmente, com o objectivo dos poemas e com a mensagem social que neles se pretende transmitir.

48. Remeto para o trabalho do autor (Campos, 1998) a discussão desta questão, uma vez que vou referir apenas alguns aspectos que considero essenciais para este texto. 
reira, 2007a: 73; Castelo-Branco, 1984: 122-4). Vale a pena citar X, 82 para expôr como o poeta resolve esta possível inquietação:

«Aqui só verdadeiros, gloriosos/ divos estão, porque eu, Saturno e Jano,/ Júpiter e Juno, fomos fabulosos/ fingidos do mortal e cego engano./ Só para fazer versos deleitosos/ servimos; e, se mais o trato humano/ nos pode dar, é só que o nome vosso/ nestas estrelas pôs o engenho vosso.»

Não há, de facto, contradição nesta questão. O modo como o Gentio ou o Mouro são representados ao longo da obra parece revelar a reivindicação da «verdade teológica», o que faz sentido quando verificamos exemplos em que a Divina Providência é integrada nos versos (II, $30-31$ e V, 60) ${ }^{49}$. A verdade histórica, por seu turno, seria o objectivo dos Cantos III e IV.

O sentimento de superação manifestado nas linhas anteriores estende-se aos conhecimentos transmitidos pela Geografia «clássica». «Vejam agora os sábios na escritura/ que segredos são estes de $\mathrm{Na}$ tura!» $(\mathrm{V}, 22)$, afirma o poeta para expressar esta opinião, pondo de manifesto a superação de obstáculos e fronteiras herdadas do mundo greco-latino. Estes textos podem, por outro lado, dar a conhecer o nome de Tarteso como rio ou como cidade, e o seu conhecimento dos seus autores, é explícito no discurso do Adamastor (V, 50, 5 - 8):

«Eu sou aquele oculto e grande cabo/A quem chamais vós outros Tormentório/ Que nunca a Ptolomeu, Pompónio, Estrabo,/ Plínio, e quantos passaram, fui notório».

49. «Assim contava [Adamastor], e c'um medonho choro/ súbuto d'ante os olhos se apartou;/ desfez-se a nuvem negra, e c'um sonoro/ bramido muito longe o mar soou./ Eu, levantando as mãos ao santo coro/ dos anjos, que tão longe nos guiou,/ a Deus pedi que removesse os duros/ casos que Adamastor contou futuros». É interessante verificar que, posteriormente, muitos autores preferiram substituir estas divindades por bruxas e feiticeiras, apresentando outro carácter às profecias que estão presentes nestes poemas (cf. Campos, 1998: 125 - 6). De referir também, como F. CasteloBranco (1984), que esta Divina Providência surge sob a forma de milagres ou revelações ao longo, por exemplo, do Canto III. Esta questão é retomada mais adiante (VI), mas por agora importa assinalar o comentário do Inquisidor Frei Bartolomeu Ferreira a esse respeito: «não achei neles coisa alguma escandalosa nem contrária à fé e bons costumes, somente me pareceu que era necessário advertir os Leitores que o Autor para encarecer a dificuldade da navegação e a entrada dos Portugueses na Índia, usa de uma ficção dos Deoses dos Gentios. Todavia como isto é poesia e fingimento, e o Autor como poeta, não pretende mais do que ornar o estilo Poético (...)» (modernizei este texto. Veja-se o texto integral, p.e., na edição d'Os Lusíadas, de H. Cidade (2005: 5).
Assinalámos, anteriormente, que esta tradição não é nova ${ }^{50}$, mas é criteriosamente transmitida no discurso de um monstro associado à superação de um dos obstáculos da viagem: o Cabo Tormentório. As palavras do Adamastor parecem querer destacar o papel dos Portugueses enquanto continuadores da Antiguidade e destacam todos os autores - à excepção de Ptolomeu - que representam, nas suas respectivas obras, Tartessos.

É neste contexto que é possível incluir paisagens limítrofes da Antiguidade, reveladas na descrição da viagem do Gama como, por exemplo, as «(...) Canárias Ilhas,/ que tiveram por nome Fortunadas» $(\mathrm{V}, 8)$. LC recorre ao nome latino Fortunatae insulae e à localização, diríamos, «definitiva» desta paisagem cujas origens podem remontar ao Antigo Egipto (Martínez, 1999: 244ss $)^{51}$. O que equivale a dizer que utiliza estes antigos confins da Geografia mítica para demonstrar a importância de uma viagem de Descobrimento como a do Gama.

Estes conhecimentos permitiriam ao poeta deter um manancial de informações de extrema utilidade para contornar, quando necessário, a métrica. Essas informações podem determinar a escolha de Tarteso como alternativa a Betis e Guadalquivir, e dão a entender que LC tinha presente um conjunto importante de referências geográficas, que manejou com a sua arte poética e com a cosmovisão ptolomaica. Teremos oportunidade de assinalar com mais pormenor este aspecto, que considero fundamental.

Os conhecimentos expostos nas Tabulae de Ptolomeu foram questionados, criticados e melhorados com os avanços na tecnologia e na cosmovisão provocados pelas navegações (cf. Barreto, 2000: 115). Neste caso particular, João de Barros é um desses críticos, enquanto que LC parece utilizar alguns dos topónimos de Ptolemeu, recorrendo a outros que existiriam nas obras

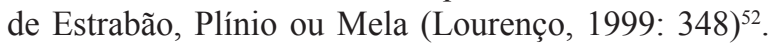
Ou seja, identificam-se n'Os Lusíadas onze nomes

50. Garcia de Resende, Pedro Nunes e Belchior Baleago, por exemplo, assinalam os progressos do conhecimento e dão um grande valor à Descoberta (Pereira, 2007: 79 -81). Para além disso, logo na primeira estância do Canto I, Camões refere a Taprobana, onde se localizava, para Plínio, o confim oriental do mundo conhecido.

51. Para uma definição clara e objectiva das ideias levantadas em torno destas ilhas, veja-se o interessante e fundamental trabalho de Marcos Martínez (1999), com bibliografia. Veja-se, igualmente, Albuquerque, 2008: 52 - 59; 2009: 98-9). Fortunatae Insulae é uma derivação geográfica de Fortunatorum Insulae (Ilhas dos Bem-aventurados)

52. Não tendo encontrado, na bibliografia recolhida e consultada qualquer estudo específico sobre Mela, Plínio e Estrabão no poema camoniano, a análise destes autores passará para o ponto VIII (Camões e Tartessos). 


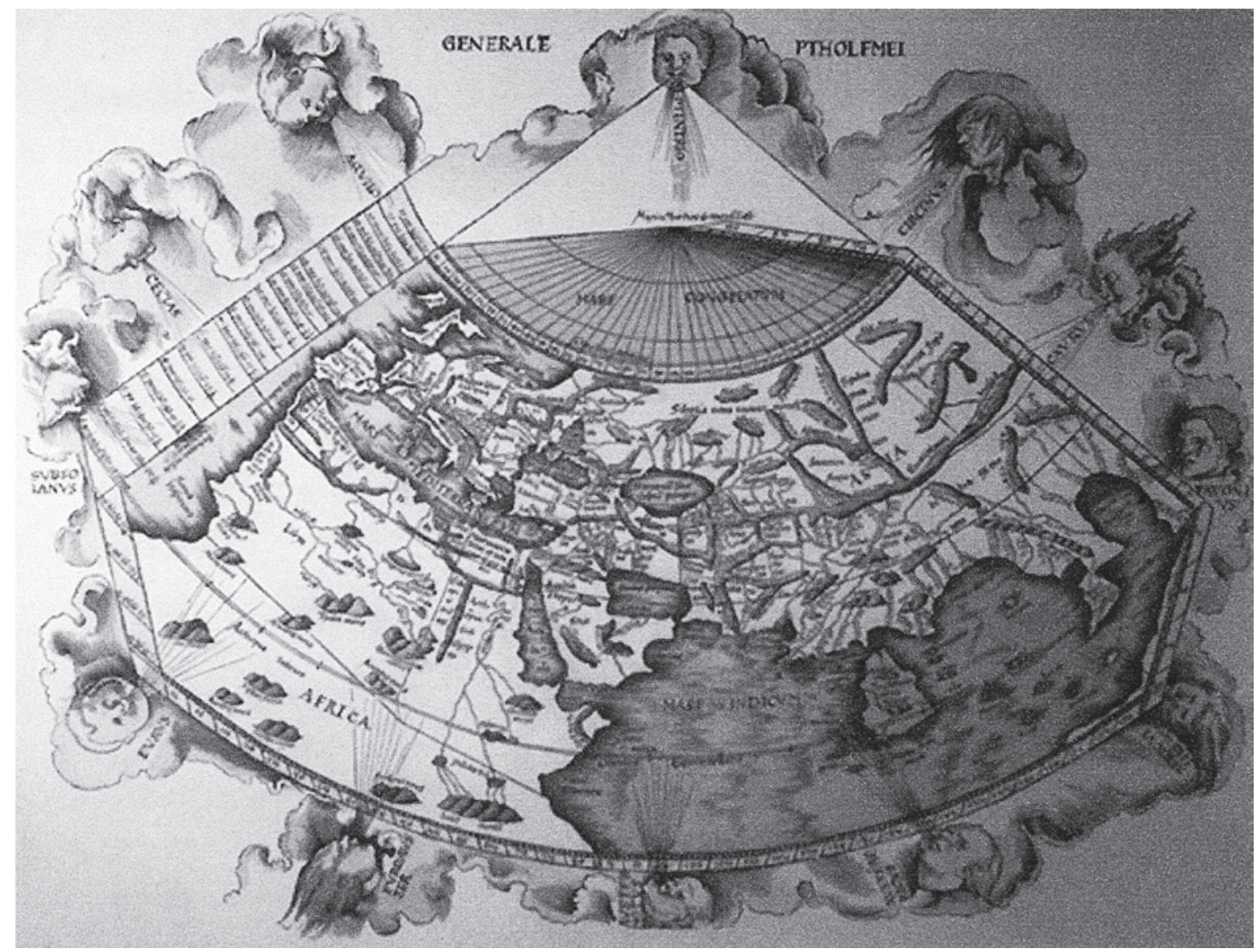

Figura 2. O Mundo de Ptolomeu, segundo Johan Scotus (1505) (http://www.henry-davis.com/MAPS/AncientWebPages/1191.html)

geográficos da Antiga Europa existentes nas Tabulae ${ }^{53}$, entre eles Bétis (Tab. 2 e III, 60), Serras da Lua (Tab. 2 e III, 56) e Monte Ártabro (Tab. 2 e IV, 28), excluindo-se Tartessos.

Rebelo Gonçalves (1950 - 1951) acrescentou a este panorama a influência de Tito Lívio (notória no pensamento de João de Barros) no poema camoniano, incidindo a sua análise sobre a sensibilidade e a postura teórica do poeta perante a História ${ }^{54}$. Teremos oca-

53. Sigo a comparação de Lourenço, 1999. Surgirá uma referência das Cartas (ou Tabulae) de Ptolomeu (p.ex., Tab. 2) seguida da referência d'Os Lusíadas. A Tabula 2 corresponde à Hispânia, pelo que me contento em referir, unicamente os topónimos peninsulares. Para os topónimos de Europa, Ásia e África, cf. Lourenço, 1999: 347 349. Para as edições da obra de Ptolomeu, cf. Exposição Bibliográfica de 1972: 226.

54. As Décadas de Tito Lívio são bastante conhecidas, destacando-se dois títulos coligidos por Pina Martins (Exposição Bibliográfica, 1972: 220 - 1): uma, completa, de 1521, e outra, um sião de comentar mais detidamente esta construção histórica ao tratar o Canto III, mas por agora importa assinalar alguns aspectos desta provável fonte de inspiração: (1) a descrição dos combates; (2) a figura do grande capitão, tida como de homem forte e sábio; (3) o factor divino na condução do destino nacional; (4) sentimento de imparcialidade/ justiça na leitura dos acontecimentos (exaltação e crítica); (5) concepção moral (por exemplo, na leitura e crítica sociais) e (6) heróica da Pátria (Gonçalves, 1950 - 1951: passim).

É com estes exemplos, toscamente enumerados, que vamos fazer uma breve leitura. Virgílio, Homero e Flaco parecem ter influenciado a construção do poema

compêndio (Compe=/ dio de las catorze Decadas/ de Tito Líuio Paduano (...), traduzido para Castelhano na Argentina (Casa de Augustin Frísio), em 1550. Acrescente-se, igualmente, as edições de 1520 (Zaragoza) 1538 (Salamanca), na colectânea de Maria Emília B. Lavoura (2001: $243-4)$. 
(como modelos), enquanto que Ptolomeu foi fundamental para a representação da geografia camoniana. Lívio, por sua vez, terá sido um modelo para a concepção da História, operando, como Virgílio, como exemplo de autores que, pela palavra, apelaram ao espírito nacional. A isto acrescentaríamos os conhecimentos de Estrabão, Mela, Plínio, entre outros que terão contribuído para a cultura do poeta.

Esta influência - se é lícito utilizar este termo - deve ser vista com as devidas reservas, uma vez que estes autores forneceram, essencialmente, conhecimentos que o poeta aproveita na construção d'Os Lusíadas. Notámos também que LC assinala a superação destes «sábios da grandíloca escritura» por parte de um herói colectivo, tanto na importância do feito como na verdade histórica contida no seu relato épico. Não só pode existir originalidade na recriação, como também não me parece viável assinalar neste trabalho qual destes autores tem maior ou menor peso no poema camoniano ${ }^{55}$ Em todo o caso, cabe ao poeta - o agente activo do processo criador - seleccionar, reformular e recriar as informações que recebeu ao longo da sua vida e que verteu para o seu discurso.

Os conhecimentos do poeta, adquiridos no estudo e na vida, não se limitam apenas a estes autores. Estendese a outros, portugueses e espanhóis, que veremos de seguida e que (novamente) não serão, exaustivamente, apresentados.

Os Lusíadas surgem num ambiente de entusiasmo generalizado da Expansão, justificando-a, juntamente com obras historiográficas portuguesas, analisadas por Rodrigues em 1905, ou coligidas por M. ${ }^{\text {a }}$ Ema T. Ferreira (1998). Faltava neste ambiente uma epopeia portuguesa, que imortalizasse, pela poesia, os feitos que os historiadores dos Descobrimentos e da Expansão deixaram por escrito. Devido, talvez, às circunstâncias próprias da sua época, a difusão da Fé e o espírito de Cruzada parecem acompanhar, lado a lado, os avanços do conhecimento científico. O que parece reflectir-se nos discursos sobre a Expansão de Castanheda, João de Barros e, claro, do nosso poeta.

Haveria, então, que destacar a proximidade destes dois discursos, épico e historiográfico, enquanto mecanismo de preservação de feitos memoráveis e de transmissão de mensagens, por vezes morais, sem esquecer as suas diferenças em termos de construção literária

55. Creio também que devem evitar-se tomadas de posição extremas, expostas de um modo deselegante nesta afirmação, subliminarmente referente a Salgado Júnior: «A detecção e análise das fontes permite corrigir juizos retortos. Temos um caso instrutivo no suposto modelo flaquiano de Os Lusíadas, em que ninguém acreditará após a leitura do presente estudo» (Carvalho, 1980: 7). O sublinhado é meu.
(Chassignet, 1998: passim). Consequentemente, ao colocar lado a lado a exposição dos Cantos III e IV d'Os Lusíadas, e a sequência genealógica da Historiografia Espanhola, parece evidente que a Poesia e a Prosa parecem ir de encontro aos mesmos temas, embora expondo-os de um modo distinto ${ }^{56}$.

A historiografia quinhentista aparenta reger-se pela obra de Tito Lívio e pelo carácter laudatório da sua heróica História de Roma. O maior ícone da sua recepção na historiografia portuguesa terá sido João de Barros, ao escrever os feitos dos Portugueses na Índia em Da Ásia, obra dividida em quatro livros ou Décadas. Terá escrito uma Geografia, irremediavelmente perdida, que poderia ser uma fonte importantíssima neste estudo. Teria este autor referido a antiga Geografia peninsular, onde se incluiria Tartessos? Não o sabemos. Como cronista-mor do Rei, João de Barros preocupouse, tal como LC, com a exposição da verdade, embora esta seja seleccionada no sentido de transmitir a ideia predeterminada: engrandecer os feitos que procura recuperar, sistematizar e transmitir, com a necessária autorização do seu protagonista, isto é, o Rei (Década I, Prólogo, apud Ferreira, 1998: 203). Sem deixar, claro, de contrastar os acontecimentos (reais) do seu presente com as façanhas fabulosas da Antiguidade. Esta obra foi impressa a 28 de Junho de 1552 , enquanto que a Segunda saíu no ano seguinte, a 24 de Março $^{57}$. Nestas duas obras, para além de Castanheda, LC terá baseado boa parte do poema, nomeadamente os episódios que marcaram a viagem de Vasco da Gama para Calecute (Rodrigues, 1905: 65ss).

Castanheda é, igualmente, um historiador que se interessou pela chegada dos Portugueses ao Oriente e que seguiu um percurso muito similar ao de Heródoto na recolha das suas informações: averiguando com os seus próprios ouvidos e olhos. O resultado é menos erudito que o da obra de Barros, mas, em todo o caso, este autor produziu um texto eficaz e condizente com os seus objectivos. A sua «enquête» incidiu sobre o mundo que Vasco da Gama conheceu com a sua viagem fundadora. Estudante do Convento escalabitano de S. Domingos, partiu para o Oriente com o seu pai (primeiro ouvidor de Goa, em 1528), junto com a armada de D. Nuno da Cunha, onde permaneceu durante vinte anos (Ferreira, 1998: 292) e onde reuniu informações em primeira mão

56. . Relembro Tito Lívio, que escreveu uma laudatória $A b$ Urbe condicta com traços épicos, do mesmo modo que LC escreveu uma Epopeia onde se encontram traços do discurso historiográfico.

57. Significa que a primeira foi publicada oito dias após a prisão do poeta (16 de Junho), que motivou a partida para a Índia em 1553, e a segunda dois dias antes da partida da Nau S. Bento, que conduziu o poeta a Calecute (W. Stork, apud Rodrigues, 1979, p. 65, n. 2) 
sobre aquilo que pretendia relatar. A sua obra, intitulada História do Descobrimento e Conquista da Índia pelos Portugueses, foi publicada em oito livros entre 6 de Março de 1551 e 1561, sendo este último póstumo ${ }^{58}$.

Se João de Barros e Castanheda foram fundamentais (como fontes historiográficas) na construção do discurso camoniano sobre a viagem de Vasco da Gama, por outro lado não podemos deixar de destacar Rui de Pina (1440 - 1522), uma vez que o seu nome está associado à escrita da «História oficial» dos reinados de D. Sancho I, D. Afonso II, D. Sancho II. D. Afonso III, D. Dinis, D. Afonso IV, D. Duarte, D. Afonso V e D. João II (Rodrigues, 1905: 85), durante o reinado deste último ${ }^{59}$. Consequentemente, torna-se incontornável na análise do discurso do Gama ao rei de Melinde, no tocante ao passado da sua nação. Atendendo à análise de Rodrigues, os «campos tartésios» não fazem parte da descrição de Rui de Pina ${ }^{60}$ (cf. Ramalho, 1984: 497).

Por outro lado, no séc. XVII, a Micrologia de J. Barreto dá conta de uma série de autores espanhóis que podiam ter alguma relação com o poema camoniano (Juan de Mena, Garcilaso de la Vega, Boscán e D. Luís de Góngora $)^{61}$. A recepção da estética poética do país vizinho não parece assumir, no contexto que tratamos aqui, uma importância extrema, uma vez que Tartessos não parece ser um tema da poesia espanhola dos sécu-

58. I (Coimbra, 1551, emendada e acrescentada em 1554), II e III (Coimbra, 1552), IV e V (Coimbra, 1553), VI e VII (Coimbra, 1554) e VIII (Coimbra, 1561), segundo Ferreira, 1998: 292. Os livros IX e X consideram-se perdidos (Rodrigues, 1979: 65, n. 1). Esta obra foi publicada pouco tempo antes do regresso de LC de Ceuta.

59. A versão digital dos originais encontram-se na base de dados digital da Biblioteca Nacional (http://purl.pt) (cons. a 29/08/09).

60. Há que ter em linha de conta as andanças do poeta, bem como as datas de publicação das várias crónicas que Rodrigues analisa, uma vez que podem fazer concordar com a ideia exposta. Jorge de Sena (1970: 166, n. 5) assinala que a de D. Afonso Henriques (Duarte Galvão) terá sido publicada em 1726. As de Rui de Pina (Sancho I, Afonso II, Sancho II, Afonso III e D. Dinis), entre 1727 e 1729, acrescentando-se a de Afonso IV, publicada em 1653 (i.e., 100 anos depois do embarque do poeta para a Índia), e as de D. Duarte e D. Afonso V, ambas de 1790. Fernão Lopes é, também, um autor cujas publicações viram a luz do dia em data mais tardia: D. Pedro I (1735), D. Fernando (1816), D. João I (1 $1^{\mathrm{a}}$ e $2^{\mathrm{a}}$ partes: 1644). As Décadas da Ásia, de João de Barros, foram impressas em $1553\left(1^{\mathrm{a}}\right.$ e $\left.2^{\mathrm{a}}\right)$ e $1563\left(3^{\mathrm{a}}\right)$, i.e., num momento em que LC se encontra fora de Portugal. A obra de Castanheda, por seu turno, viu os três primeiros livros impressos em $1551-2$, do $4^{\circ}$ ao $7^{\circ}$ em 1556 e o $8^{\circ}$ em 1561 . É, por isso, mais provável o conhecimento directo de Castanheda ou de Barros, sem excluir, obviamente, os sumários destas obras, mais acessíveis. No entanto, J. de Sena não parece considerar a circulação de informações orais (que, p.e., sustentam o método historiográfico de Castanheda). Estas foram recolhidas na Índia, o que abre a possibilidade de aquisição de informações neste país por parte de LC.

61. De acordo com o comentário introdutório à edição de 1982 por Aníbal Pinto de Castro. los XV e XVI (?). No entanto, tanto Pedro de Medina (1548) como Florián de Ocampo (1541; 1543; 1553; cf. Lavoura, 2001: 305 - 306), para citar apenas dois autores anteriores a LC, tratam este assunto com alguma profundidade e não são mencionados por Barreto.

Quer isto dizer que uma hipotética presença da Historiografia espanhola no poema camoniano ainda não foi sujeita a uma análise mais profunda, pelo menos na produção intelectual dos estudos camonianos no século XX. Maioritariamente, estes estudos concentram-se na poesia espanhola quando procuram averiguar estas relações. Mesmo o comentário de Faria e Sousa a VIII, 29 assinala Juan de Mariana e Tomas Tamayo, revelando que, provavelmente, desconhecia Pedro de Medina e Ocampo. Já Epifânio Dias não assinala Pedro de Medina nestes contextos, como fez, por exemplo, no seu comentário a III, 17.

A tela de fundo da Historiografia Espanhola parece ser diferente daquela que norteou o mesmo discurso em Portugal, sobretudo por questões políticas. Aos "Lusíadas" interessava discursar e reflectir a Expansão do conhecimento e da Fé. O discurso da Crónica de Florián de Ocampo, historiador oficial de Carlos V, apresentava duas faces: uma, voltada para o interior, destinava-se a promover a unidade (política, religiosa e territorial) do povo espanhol; outra, orientada para o exterior, legitimava a política expansionista dos Reis Católicos (Martí - Aguilar, 2000: 3). O século XVI marca, assim, a consolidação de uma tradição historiográfica que remontava ao Génesis veterotestamentário as raízes da realeza espanhola. Visto que, neste contexto, LC seria um receptor externo, é muito provável que a questão não tenha despertado o seu interesse, visto que promove na sua obra um sentimento de independência que não se adequa ao discurso historiográfico do outro lado da fronteira.

Não obstante, é momento de fazer um balanço, começando por assinalar que

«Na obra de um poeta, por mais genial que seja a sua originalidade, há sempre matéria larga para inventariar, quer o legado espiritual que herdou ou que lhe foi transmitido pela geração a que a sua dá continuidade, quer o que ele próprio pessoalmente assimilou dos ambientes de facto ou ideias por que lhe decorreu a vida.»

Hernâni Cidade, 2004: 9.

A inventariação das «fontes» de LC é um desiderato de difícil conclusão e não deve cingir-se à leitura do poema. Isto porque, como oportunamente assinala R.M. Rosado Fernandes (1980: 3), o poeta é, ao mesmo tempo que o agente de recriação, co-herdeiro 
dessa tradição (historicamente localizada) de recepção do legado literário da Antiguidade. Este aspecto levanta um problema fundamental, já assinalado: o do contacto «em primeira mão» com estes textos. Um exemplo parece ser o de Tito Lívio, que inspirou João de Barros, enquanto que este terá inspirado algumas passagens d'Os Lusíadas ${ }^{62}$.

A crítica camoniana concentrou-se, desde os seus primórdios, no estudo das fontes (quellenforschung), originando um conjunto de abordagens interessante. Não é assunto deste trabalho assinalar todas as considerações que se teceram sobre esta questão ao longo de quatro séculos de leituras d'Os Lusíadas, sendo um estudo que está muito longe das minhas capacidades. Tal não impede de assinalar dois trabalhos importantes: a edição d'Os Lusíadas comentadas por Faria e Sousa (1639) e uma edição de $1670^{63}$, onde surge, pela primeira vez, um índice de nomes próprios, da autoria de Franco Barreto, que originou a Micrologia.

Existem diferenças fundamentais entre uma e outra obra. Enquanto que a primeira explica o conteúdo de cada estrofe, a segunda elabora uma espécie de dicionário, ordenado alfabeticamente, como surge explícito no título: Micrologia/ em a qual se explicam todos os nomes próprios, istorias, fabulas, nomes peregrinos e lugares escuros conteudos em os Lusíadas de Luis de Camões (...). Com um comentário de grande erudição, Barreto apresenta um conjunto importante de referências sobre Tartessos, indo mais longe do que o próprio Faria e Sousa no tocante a termos como Bétis, Guadalquivir, Tarifa e Tartessos. Reflecte um extraordinário sentido crítico que vai de encontro à explicação desses nomes no poema, às autoridades e à discussão de algumas opiniões de um modo que pretendia esclarecedor para qualquer leitor do texto camoniano.

Estando seguro de que este texto terá conseguido chegar a uma pequena parcela desta realidade, uma ilação a tirar é a necessidade de um estudo mais profundo sobre estas questões, que englobasse múltiplas perspectivas e disciplinas, não só do poema camoniano, como também dos outros autores que terão servido de base à elaboração d'Os Lusíadas. Neste sentido, haveria que assinalar que o tema em análise - Tartessos em LC está entre estes dois campos, levantando dificuldades que o autor destas linhas procurou superar. Vejamos, agora, os Cantos onde LC inseriu Tartessos.

62. Ver nota 54

63. Trata-se da reedição de uma publicação de 1663, «que apresentava a novidade de trazer, à cabeça de cada canto, o argumento ou súmula do seu conteúdo (...)» (prefácio A.P. de Castro à obra de Barreto, 1982: XV). As edições de 1663 e 1670 foram impressas ba casa de António Craesbeek de Melo.

\section{O CANTO III}

«Mas tu, em quem mui certo confiamos/ acharse mais verdade, ó Rei benigno, e aquela certa ajuda em ti esperamos, que teve o perdido Ítaco em Alcino;/ A teu porto seguro navegamos,/ conduzidos do intérprete divino,/ que - pois a ti nos manda - está mui claro/ que és de peito sincero, humano e raro.»

Os Lusíadas, II, 82

Um primeiro aspecto que se destaca nesta estrofe é a presença do Rei de Melinde como personagem ajudante e como protagonista de uma cena-tipo da narrativa de viagem: a hospitalidade. A forma, de acordo com o pensamento de Propp, determina o conteúdo (Morfologia Skazki = Propp, 2006), o que é válido, por exemplo, para a anterior análise das influências de Virgílio, Homero e Flaco n'Os Lusíadas. Não se trata de reduzir a riqueza do poema às sequências estáveis de Propp, mas antes de assinalar que este episódio é fundamental, uma vez que permite ao poeta, inspirado pela Musa, introduzir uma mensagem pela «boca» do protagonista. O mesmo ocorre no Canto VIII com a curiosidade do Catual.

Este papel é detido, na Odisseia, por Alcínoo, que pede a Odisseu que descreva os homens cruéis, injustos, amigos do estrangeiro ${ }^{64}$ e com temor aos deuses (Od. VIII, 572 - 6 e IX, 170 - 176). Na Eneida (II e III), por seu turno, a hospitalidade de Dido permite introduzir a vida de Eneias (cf. Pinho, 2007a).

Isto em relação às semelhanças. A diferença fundamental é que o episódio narrado por LC reflecte uma etapa da viagem de Vasco da Gama, se seguirmos o relato do Piloto e de outros historiadores contemporâneos do navegante português (Campos, 1998: 122) ${ }^{65}$. Neste sentido, o ouvinte é colocado na sequência, vivendoa intensamente: o discurso narrativo, através da sua linearidade e simplicidade, torna os "factos", mesmo os incoerentes, mais assimiláveis e compreensíveis, perpetuando e fazendo ressonância do pensamento que se pretende dominante. Note-se que a intervenção do poeta nos Cantos III e IV é quase inexistente, cabendo a

64. Albuquerque (em prep.), onde exponho o porquê de considerar que o termo $\varphi \imath \lambda o ́ \xi \varepsilon t v o \varsigma$ deve ser traduzido como «amigo do estrangeiro» e não como «amigo do hóspede». Das quatro vezes que o termo é utilizado na Odisseia, o sentido de $\varphi \imath \lambda$ ó $\xi \varepsilon ı v o \varsigma$ enquadra-se em situações em que o protagonista ainda não foi reconhecido pelos seus anfitriões. Ou seja, mesmo considerando o duplo sentido de $\xi \varepsilon i ̃ v o \zeta$ como «estrangeiro» e «hóspede», parece evidente que, antes de ser reconhecido como «hóspede» (h. antigo da família ou novo h.), aquele que chega e beneficia da hospitalidade é «estrangeiro».

65. Gaspar Correia, João de Barros e Damião de Góis. Para as restantes etapas da viagem, cf. Ferreira, 1998: 77. 
primazia à História de Portugal (143 estrofes no III e 104 no IV), tal como é salientado por J. de Sena (tabela 1), que por sua vez não é assinalada ao longo de todos os restantes Cantos.

Neste contexto, há que verificar a distribuição dos temas ao longo das estrofes do Canto III, de modo a poder «isolar» Tartessos.

Vasco da Gama descreve a Europa (III, 6 - 20), ao ponto de dar a sensação, como muito bem aponta Sebastião Pinho (2007b: 137), de que se está perante uma carta cosmográfica. Entre a estrofe 6 e a 20 deste Canto, sobressaem alguns aspectos que foram apontados por A. Salgado Júnior (1949) em relação à visão humanista da Geografia quinhentista. Um desses aspectos é a concepção do Homem enquanto Ser permanente e enquanto produto da sua geografia ${ }^{66}$, a ponto de fazer integrar neste Canto a representação de duas Europas, em tudo coincidentes com o mapa geo-político Romano: a Europa Bárbara por um lado (LC inicia a analepse no $\mathrm{NE}$ europeu) e a Europa do Império por outro, na procura de um equilíbrio entre a configuração antiga e a moderna da sua Europa, apreendida e representada com os olhos de um humanista.

Particularmente interessante é a "visualização" da Espanha (17 - 19), em que LC lidou com duas realidades distintas - a divisão das províncias romanas e a sua actualidade política -, no meio das quais havia o processo de conquista de terras aos Muçulmanos (que não retomou esta divisão). O poeta integrou esta antiga realidade nas estrofes 17 - 19, sobretudo na última, citando o Tarragonês, as Astúrias, o Galego e Bétis como antigas realidades da Hispânia (Tarraconensis, Gallaecia, Asturia e Baetica), equilibrando-as com Navarra, Castela, Leão e Granada. Aragão parece ser assimilada a Tarraco, se tivermos em consideração o Dictionarium de Nebrija, como aponta Salgado Júnior (1949: 289).

Toda esta ordem geográfica, iniciada com a Europa do NE, tem por objectivo terminar na Lusitânia para, a partir daí, iniciar o discurso sobre a «sanguinosa guerra». Antes disso, detenhamo-nos mais um pouco na «larga terra», assinalando um aspecto tão

66. Embora não seja evidente nesta descrição, bem como na apresentação mais lata da «Máquina do Mundo», as considerações que Salgado Júnior tece em torno da questão dão a entender que LC faz uso da concepção determinista de Aristóteles (cf. Política VII, 7), aproveitada, politicamente, para justificar a escravatura (Bernal, 1993: 196 - 7). Isto porque, assinala aquele autor (1949: 282) que LC assinala mais diferenças entre os Europeus Modernos e os Africanos e Asiáticos seus contemporâneos do que entre o Europeu Antigo e o Europeu Moderno, sendo neste contexto que deve entender-se o sentido de "permanência" do Homem Europeu, idenficado por LC com o Homem do Imperium Romano (o Império Turco era considerado como artificial e transitório). importante como interessante da representação da Europa camoniana:

«Eis aqui se descobre a nobre Espanha,/ como $\mathrm{ca}$ -

beça ali da Europa toda (...) (III, 17).

«Eis aqui, quase cume da cabeça/ de Europa toda, o Reino Lusitano» (III, 20).

Depois de Borges de Figueiredo (1883a: 22) comentar, sumariamente, estas passagens, Epifânio da Silva Dias (ed. 1972) assinalou a obra de Pedro de Medina e a História de S. Domingos (I, 2, 4), de Frei Luís de Sousa, como fontes literárias de LC para a elaboração desta descrição (Ribeiro, 1971 Pinho, 2007: 142$3)^{67}$. Para Pinho, esta sugestão não é convincente, uma vez que existiriam, naquele tempo, representações iconográficas ginecomórficas da Europa, nomeadamente a de Johan Pusch, publicada por Christian Wechel em Paris (1537; fig. 4), cujas origens podem rastrear-se já no século XIV, no Mapa «Opicinus de Canistris», datado de 1334 - 1338 (Pinho, 2007b: 159, mapa XI; fig. 3) ${ }^{68}$. Estas representações são, provavelmente, as únicas anteriores a LC, visto que a sua proliferação, pelas mãos de Heinrich Bunting, se dá após a morte do poeta em 1580 (Fig. 5). Outra hipótese é a consulta, por parte de LC, do Compendium Geographiae Disciplinae (Basileia: Ioannem Oporinum), da autoria de Guillaume de Postel, publicada em 1561, quando o poeta se encontrava fora de Portugal. O autor deste Compendium refere C. Wechel, descrevendo também uma Europa ginecomórfica ${ }^{69}$.

67. Ribeiro (1971) faz uma pequena nota a Epifânio Dias, bem como à Etnografia Portuguesa de J. Leite de Vasconcellos (1936), que abre com a citação de Lusíadas III, 20. Tomei contacto com esta sugestão depois da consulta da obra de Pedro de Medina, na qual se encontra, como veremos a seu tempo, esta mesma descrição (Cap. I). Foi com esta referência que decidi aprofundar um pouco mais a questão da representação da Europa por parte de LC, visto que poderia haver aqui uma indicação complementar à ideia de que Pedro de Medina pode, igualmente, ter sido consultado pelo poeta, a julgar também pela coincidência da interpretação de Tartessos como Carteia (i.é., Tarifa).

68. Codice Vaticano Latino 6435 , fol. $84 \mathrm{v}$

69. Ao que deve acrescentar-se que o coração representa o berço dos Habsburgo (figs. 4 e 5). A representação da Roma Imperial como um símbolo universalizante parece ter feito com que os poderes peninsulares projectassem sobre os novos mundos descobertos esta concepção. A «Espanha, cabeça ali da Europa toda» parece sintetizar este sentimento de universalização, sobretudo da Fé. Esta imagem serviu de suporte iconográfico ao Rei espanhol Filipe II, coroado em 1556, que se afirmava como «un nuevo Augusto Cristiano, el heredero de los emperadores romanos y cristianos y el elegido por dios para regir el mundo» (Villá i Tomás, 2001: 266). Veja-se, igualmente, Pinho, 2007b: passim. 


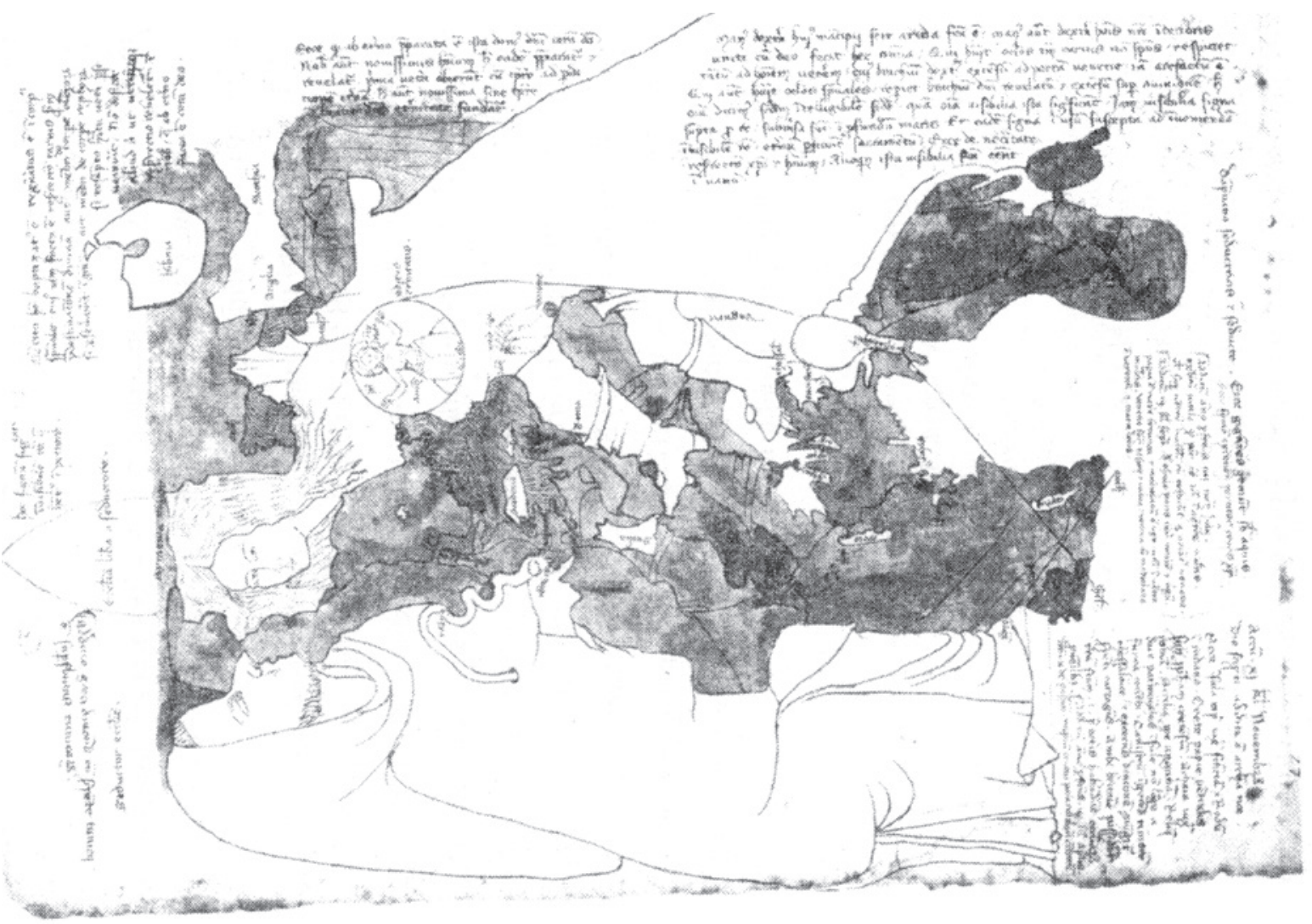

Figura 3. Opicinus de Canistris, «Ecclesia libera a seductore» http://www.henry-davis.com/MAPS/LMwebpages/230.html (cons. 6/10/09)*

Pedro de Medina, Postel e a cartografia ginecomórfica da Europa são três hipóteses prováveis e que não se excluem mutuamente ${ }^{70}$. O significado do termo quasi, exposto no poema camoniano (III, 20), pode ser um elemento de análise da última hipótese. Trata-se, eventualmente, de um latinismo que não adquire um sentido espacial, mas antes o de «como que» (Pinho, 2007b: 167). Acrescenta este autor que «a imagem da figura feminina dos mapas ginecomórficos confirma esta posição absoluta [como extremo ocidental da Europa] quando apresenta Lusitania gravada na parte superior

70. Cf. supra a citação da Geographia de João de Barros, hoje irremediavelmente perdida, que pode ter sido, segundo Orlando Ribeiro (1980: 159-160 e 175-176) a principal fonte do conhecimento geográfico de LC, a par de Ptolomeu. Em 1980, encontrava-se em preparação uma Geografia Restituta, da autoria de O. Ribeiro e S Daveau. Uma pesquisa na base de dados da BN e da Biblioteca da Faculdade de Letras na Universidade de Lisboa não revelou qualquer resultado, pressupondo-se que este trabalho nunca chegou a ser publicado. Quanto a Pedro de Medina, a análise que será adiante pode reforçar a proposta de Epifânio Dias. da haste frontal da coroa da jovem rainha e lhe sobrepõe, ainda, o escudo de armas de Portugal, de modo a não deixar qualquer espaço superior vazio» (id., ibid.). No entanto, a julgar pelo carácter visualista de descrição camoniana, é possível que LC se refira, com precisão e mestria, a uma representação iconográfica e não tanto a um texto.

Esta característica, consubstanciada pela aparição do verbo «Ver» por 444 vezes n'Os Lusíadas (o mais frequente a seguir ao verbo «Ser», com 697), volta a repetir-se no Canto VIII, que vamos ver de seguida, bem como no Canto $\mathrm{X}$ que, pela própria natureza da análise aqui proposta, não vai ser considerada.

A «sanguinosa guerra» (História de Portugal) é, então, enquadrada neste excurso geográfico e, «no conjunto, ocupa uma parte considerável do poema» (Castelo-Branco, 1984: 115), detendo o segundo lugar dos

* Para outras versões deste mapa, veja-se, no mesmo site (cons. 6/10/09): http://www.henry-davis.com/MAPS/LMwebpages/230A. html (/230B.html; /230B3.html; /230C.html) 


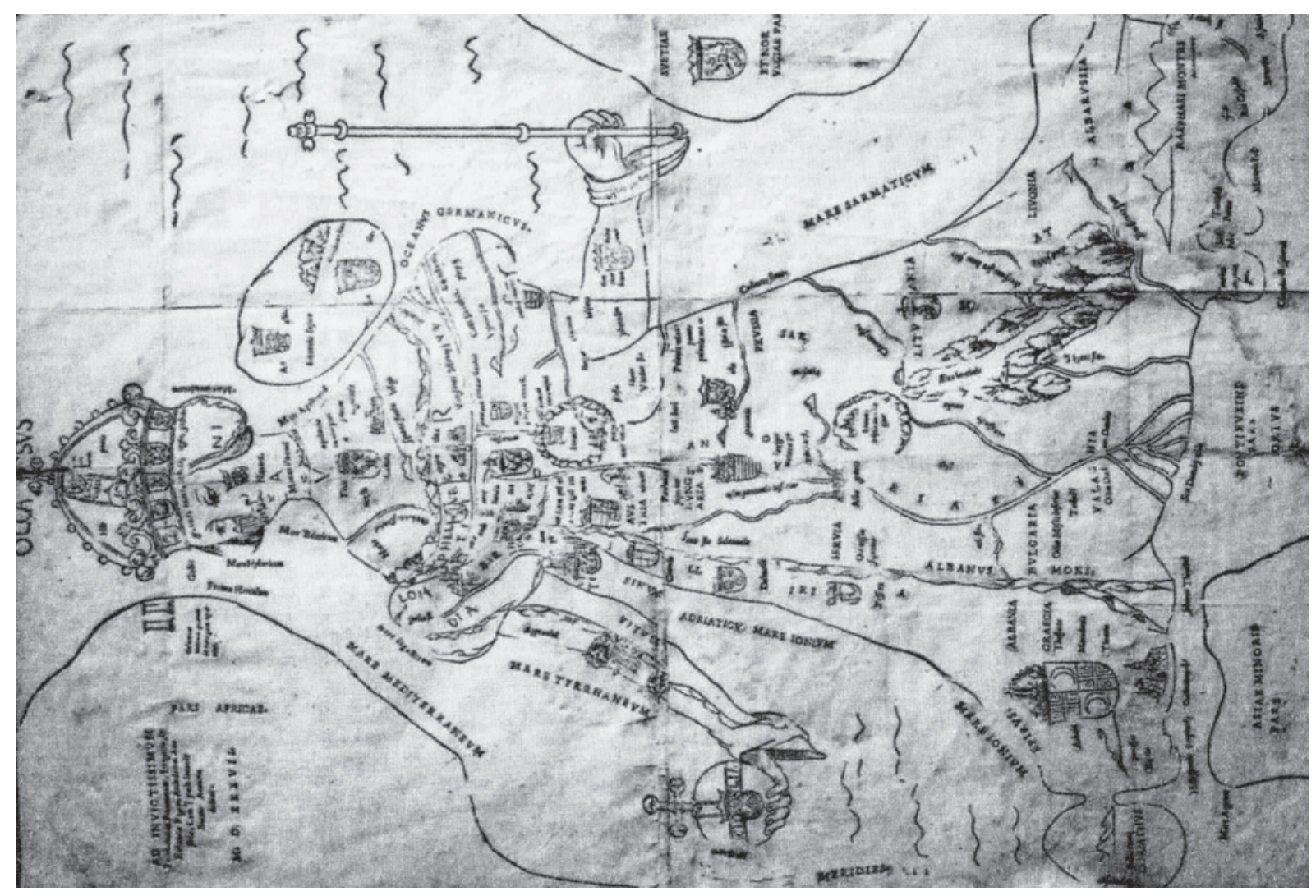

Figura 4. Europa - Virgo, de Johan Pusch (1537), apud Pinho, 2007b

temas tratados por LC, com 245 estrofes, logo a seguir à viagem (cf. Tabela 1). É neste contexto e (note-se) não no anterior que surge a referência aos campos tartésios.

Esta importância deriva da própria vida do poeta, decorrida entre as armas e as letras (Berardinelli, 2000: 57 - 58), como manifesta em VII, 7971. Revelador é, também, o tratamento que dá no Canto III às batalhas de Ourique (42ss) e Salado (99 - 117), e pelo destaque que dá ao percurso dos reis: D. Afonso Henriques (III, $42-68$ e $77-82)$, outros reinados $(85-90$ e $94-$ 95), D. Dinis (III, 96 - 98) e D. Fernando (138 - 143). No caso de Inês de Castro (118 - 136), Paulo Oliveira (1998) assinala que o poeta valoriza este espisódio por apresentar um fim literário.

A importância conferida a D. Afonso Henriques e às Batalhas de Ourique e do Salado revelam que a temática

71. «Olhai que há tanto tempo que, cantando/ o vosso Tejo e os vossos Lusitanos,/ a Fortuna me traz peregrinando,/ novos trabalhos vendo e novos danos:/ agora o mar, agora esperimentando/ os perigos Mavórcios inumanos,/ qual Cânace, que à morte condena,/nu[m] a mão sempre a espada e noutra a pena» (o verso 8 é citado por Berardinelli, 2000: da «Guerra Santa» assume grande relevância no espírito do poeta, acrescentando-se que «(...) quando, no canto oitavo, Paulo da Gama fala sobre as figuras pintadas nas bandeiras, a luta contra os mouros será, novamente, um aspecto recorrente» (Oliveira, 1998: 415). Ou seja, revelam o que se entende como «visão camoniana da História», na qual a luta contra o Mouro e a afirmação da independência de Portugal face a Castela (durante a Revolução de 1383, exposta já no Canto IV e retomada no VIII) assumem o lugar de maior destaque, desvalorizando-se o Povo enquanto interveniente deste processo (Castelo - Branco, 1984: 126 - 130).

A História de Portugal, apresentada pelo Gama, dá a entender que o poeta a apreende e transmite com um sentido moral e político, aproximando-se da concepção da História como magistra vitae ${ }^{72}$ ou como exemplo

72. Só no Canto III: 31, 33, 69, 74, 136 e 139, com críticas negativas; 41, como exaltação. Acrescentam-se outras do Canto IV, das quais prescindimos $(4,44,57-58$ e 95). Estes excertos são citados, neste mesmo contexto, por F. Castelo - Branco (1984: 116 119), artigo para o qual remeto um complemento útil desta questão. J.V. de Pina Martins (1981: XX) também salienta a crítica social camoniana, em parte baseada em Erasmo e Petrarca. M. ${ }^{a}$ H. da Rocha 


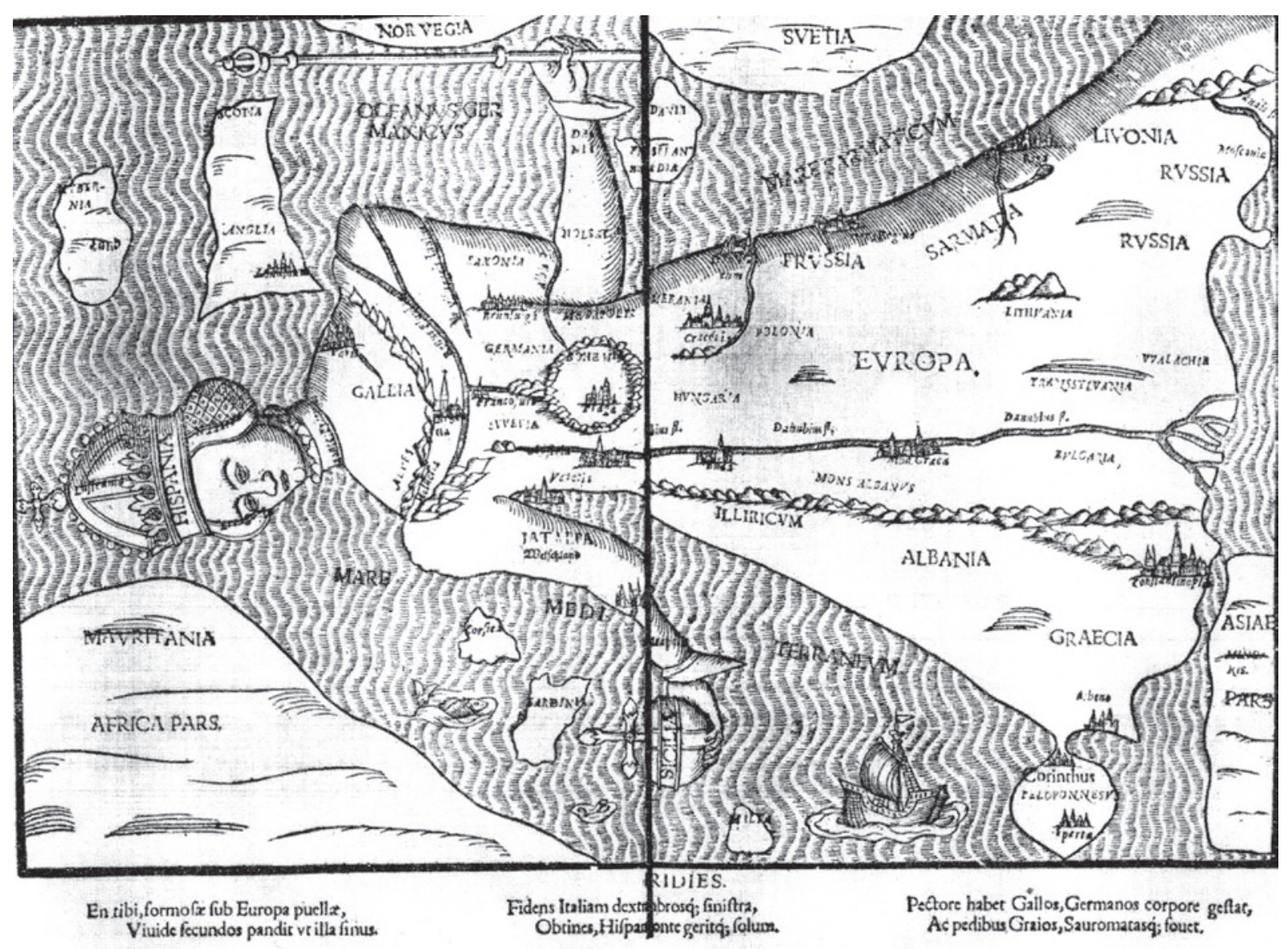

Figura 5. Europa [...] in forma virginis. Itinerarium Sacrae Scripturae, Halmstadt (1581/ 1587) (apud Vilá i Tomàs, 2001: 266)

da grandeza de um povo (Tito Lívio, Tácito; cf. Hartog \& Casevitz, 1999: 190ss). LC parece também recorrer à Divina Providência, como apontámos no contexto da presença da mitologia greco-latina no poema, para apresentar episódios de guerra como o cerco de Santarém (III, 82), a Batalha do Salado (III, 110) $)^{73}$, ou mesmo no milagre ocorrido em Ourique, sobre o qual

Pereira (2007b) salienta que, em X, 154. 5-8 (v. supra, esta estrofe), LC aponta três características fundamentais do orador, definidas por Cícero: «estudo», «experiência» e «engenho» (citando Corrêa da Silva). Para além disso, Cícero deve ser valorizado (a par de Dionísio de Halicarnasso, Quintiliano, Plínio-o-Moço, Salústio e Plutarco) como defensor da ideia da História como magistra vitae (cf. Hartog \& Casevitz, 1999: 146 - 181).

73. Nesta, destaca-se a diferença numérica dos soldados de um e outro lado do campo de batalha, em claro desfavor dos Cristãos: «Estão de Agar os netos quase rindo/ do poder dos Cristãos, fraco e pequeno,/ as terras como suas repartindo/ antemão, entre o exército agareno,/ que, com título falso, possuindo/ está o famoso nome «Sarraceno»;/ assi também com falsa conta e nua/ à nobre terra alheia chamam sua». assenta a aclamação de D. Afonso Henriques como Rei (III, $45-46)^{74}$. Este aspecto dá a entender que LC se baseia no Providencialismo Histórico (ou finalista teológico) de Santo Agostinho. Para o autor da Cidade de Deus, esta entidade divina é um «regulador omnisciente e omnividente da história» (Soares, 2004: 433), pelo menos desde Caim, a partir do qual surgem as duas cidades (Hartog \& Casevitz, 1999: 260 - 264). A História apresentada pelo Gama parece, por seu turno, querer provar que Portugal - e a sua realeza - era um país eleito e protegido por Deus, detendo a missão de expandir a Fé75.

74. A questão dos milagres na exposição histórica camoniana entronca com a discussão levantada em torno de LC enquanto «Cristão-novo» (Castelo - Branco, 1984: 122 - 4).

75. M. ${ }^{a}$ Luísa Castro Soares (2004) chega a utilizar o excerto de III, 20, anteriormente apontado para explicar a concepção da cartografia ginecomórfica, num outro sentido, isto é, a «cabeça/ da Europa toda» significa «cabeça do império temporal de Deus na terra». 
Os campos tartésios surgem, então, integrados num discurso histórico que valoriza a luta contra o Mouro (Batalha do Salado), excluindo-se do discurso geográfico. Voltaremos a verificar a pouca importância deste tema no Canto VIII.

\section{O CANTO VIII}

Este Canto é marcado por uma magnífica exposição que coloca o ouvinte/ leitor perante uma sequência iconográfica de 25 personagens, com o mesmo carácter visualista apontado para a descrição da Europa (Pinho, 2007b: 133ss). O papel do Catual, que pede a Paulo da Gama a explicação do significado das bandeiras, é, por isso, similar ao do Rei de Melinde.

Tal como no Canto III, o primeiro nome que surge é o de Luso: «Este que vês, é Luso, donde a fama/ O nosso Reino Lusitânia chama» (VIII, 2). Curiosamente, LC parece dar um sentido escatológico à Península Ibérica: «Do Douro e Guadiana o campo ufano/, já dito Elísio, tanto o contentou,/ que ali quis dar aos já cansados ossos/ eterna sepultura e nome aos nossos» (VIII, 3$)^{76}$. Os outros que se seguem parecem ser, criteriosamente, escolhidos, atendendo ao comentário de J. de Sena à estrutura deste canto: «As bandeiras que o Gama levava consigo, para ilustrar-nos complementarmente acerca da História narrada nos Cantos III e IV, não tinham, nas suas figuras, ninguém morto havia menos de trinta e três anos da sua partida de Lisboa. Isto é como se, para figurar-se numa bandeira, fosse necessário um período purgatório, igual à idade perfeita, a de Cristo... Por outro lado, Camões não insere, nas bandeiras, ninguém morto depois de 97 anos de diferença para a data máxima que inclui (e nas profecias) no poema (cerca de um século)» (1980: 154 - 5, os sublinhados são do autor).

Mesmo excluindo este comentário, verifica-se que o objecto central desta descrição das bandeiras está muito longe de poder integrar o rio Tarteso como um elemento preponderante da História de Portugal, tal como se verificaria no Canto III. No entanto, o discurso descritivo e visualista de Paula da Gama, dirigido ao Catual, ocupa 42 de 99 Estâncias $(1$ - 42), enquanto que outras 50 são dedicadas à viagem $(43$ - 46; 51 96), 4 aos deuses (com a última intervenção de Baco no poema, em 47 - 50) e 3 à intervenção do poeta (97 - 99)

76. cf., supra, a questão dos «Lusíadas» ou «filhos de Luso». Pode levantar-se uma questão interessante em torno deste aspecto, tendo em linha de conta que Luso é filho de Baco e que este tem uma postura agressiva contra os seus descendentes. Para um melhor esclarecimento desta aparente contradição, cf. Jorge de Sena (1980: 154). sobre a traição (Sena, 1980: 117 e 155). Este Canto, de acordo com a análise de H.Post (1972: 312 - 313), terá sido escrito durante a estadia de LC em Goa (1553 - 1556; 1560 - 1567), embora o autor seja cauteloso nesta afirmação.

Começa a desenhar-se um pequeno panorama da pouca importância de Tartessos no poema camoniano, parecendo mostrar que uma razão plausível para a introdução de deste nome é a métrica.

\section{MÉTRICA}

A Métrica - do Grego metrikê - é, por definição, uma construção baseada na sequência de sílabas que compõem um verso. A sua análise (quantitativa) não só pressupõe a compreensão da formulação do verso, como também, neste caso, permite reconstituir um conjunto determinado de opções que LC pode ter manejado (Gomes, 1999: cols. $748-9)^{77}$.

Antes de ver as implicações desta regra no poema camoniano, deve assinalar-se a diferença entre a métrica grega (metra)/ latina (pé) e a das línguas românicas. Na primeira, é necessária uma alternância entre sílabas longas e breves existentes num verso. A segunda fundamenta-se numa construção silábico - acentual, em que o ritmo é marcado pela intensidade das sílabas (átonas e tónicas).

A partir do segundo quartel do século XVI, o decassílabo italiano entra em Portugal com o regresso de Sá de Miranda que, entre 1521 e 1526, esteve em Itália. De acordo com esta concepção, o verso heróico devia ter duas sílabas tónicas $\left(6^{\mathrm{a}}\right.$ e $\left.10^{\mathrm{a}}\right)$. É este esquema que LC adopta na construção do seu poema ${ }^{78}$ e que vai pesar na reconstituição de alguns sinónimos que o próprio poema oferece. Em muitos casos, estas imposições terão obrigado o poeta a fazer algumas escolhas entre os vários significados de termos que precisava de utilizar, entre eles topónimos, hidronímicos, corónimos, etc. Neste sentido, os campos tartésios seriam um sinónimo de campos de Tarifa, que LC refere mais adiante no seu poema (III, 108). Do mesmo modo, o rio Tartesso encontra correspondência com Betis (III, 19, 60 e 85), Guadalquibir (IV, 9) e «o rio que Sevilha vai banhando» (III, 75).

Permita-se-me exemplificar. Em III, 108, LC escreve: «Juntos os dois Afonsos, finalmente/ nos campos de Tarifa estão defronte/ da grande multidão de

77. As considerações deste capítulo baseiam-se neste artigo.

78. Para uma exposição das variantes da Métrica, cf. Gomes, 1999: passim, bem como a bibliografia aí referida. 
cega gente». Vejamos a segunda opção neste encadeamento: [nos campos tartésios estão defronte]. A $6^{\mathrm{a}}$ e $10^{\mathrm{a}}$ sílabas (assinaladas a negrito) são átonas. Do mesmo modo, tão-pouco poderia o poeta escrever, em III, 100, [foram nos campos de Tarifa ajuntada], precisamente pelo mesmo motivo. $\mathrm{O}$ mesmo pode aplicar-se à leitura de VIII, 29.

Colocando a hipótese nestes termos, teríamos uma resposta viável para a introdução de campos tartesios em III, 100, e Tarteso em VIII, 29. Note-se que estas alternativas encontram-se todas nos Cantos III e IV que, como vimos, foram consagrados à exposição da descrição da terra e à História de Portugal, apresentando uma composição silábica distinta. Assim, falta responder a uma outra questão: a proveniência das interpretações de Tartessos como cidade associada a Tarifa, e como um rio que se chamou Betis e, no tempo de LC, Guadalquibir.

\section{TARTESSOS N'OS LUSÍADAS}

Deparamo-nos com um problema de fontes. As que J.M. ${ }^{a}$ Rodrigues aponta não permitem uma correspondência directa com os oitavos versos, o que obriga, naturalmente, a procurar outras alternativas que possam ser coerentes e possíveis. Esta ausência dos comentários do autor de Fontes dos Lusíadas é explicável se tivermos em linha de conta que em nenhuma das fontes portuguesas e italianas que analisou (relembro que desvalorizou as espanholas) parece haver uma ligação a Tartessos. Parto do princípio (talvez equivocado) que LC é o primeiro autor, daqueles que se apontaram, a colocar aquele nome na história da recepção renascentista portuguesa.

Para permitir uma confrontação mais ajustada, vejamos o que Rodrigues (1905: 105) cita de Rui de Pina:

«[ElRey de Marrocos, Alliboacem] passou em pessoa \& veyo há Aljazira y cõ elle, segundo o mais comum testemunho, passaram dos acontiados \& perçebidos sessenta myl de cauallo \& quatro çentos myl homeens de pee, com que tamben se ajuntou ElRey de Graada com todo seu poder... Domingo a XXVII dias do mees de Outubro chegaram (os dous reus christãos) a pena do çeruo, donde os espantosos arrayaes dos mouros ia pareciam sobre Tariffa...»

Cronica del rei dom affonso (...), fls. 52 e $52 \mathrm{v}$

Os Lusíadas III, 100 e este excerto da Crónica de Rui de Pina mostram como um discurso sobre o mesmo tema pode variar em termos de composição, embora apresentem uma terminologia comum. Enquanto que o primeiro utiliza Tartessos como Tarifa, o segundo menciona apenas este segundo topónimo.

Surgem duas hipóteses viáveis: a primeira relaciona-se com a Geografia antiga e o segundo com a Historiografia. Excluindo Rui de Pina, pela ausência de Tartessos no seu texto, resta procurar fontes onde o tema - e, inclusive, a relação Tartessos/ Tarifa - pode interessar, e aí teríamos de recorrer à historiografia espanhola contemporânea de LC, bem como a outros autores da Antiguidade, adiante expostos, que localizam Tartessos em Carteia.

Esta relação foi valorizada por Pedro de Medina quando escreve o Libro de Grandezas y cosas memorables de España, publicado em 1548. Voltaremos a esta obra mais adiante, mas importa reter que este autor também trata a batalha que LC e RP assinalam e não é considerado por Faria e Sousa que, ao comentar III, 100 e VIII, 29, afirma:

[III, 100]. Os Campos Tartesios. Está dicho con Ausonio epist.19 Tartesia Calpe son aquellas tierras que yacen vezinas al promontorio Calpe, llamadas assi por Tarifa, que se llamo Tartesia, Ciudad puesta a las raizes de las colunas de Hercules, fin de España; $i$ una dellas es este monte: $i$ en esta campaña se juntò essa Morisma, i fue vencida de los Reyes Portugues, i Castellano.

[VIII, 29] Que entre o Tarteso, e o Guadiana habita. Quiere dezir, la gente de Andaluzia, mas particularmente de aquella que habita entre o rio Guadiana, $\mathrm{i}$ el Guadalquivir, que ya se llamó Tarteso: de que diximos sobre la e. 100 del c.3. I véanse los Geografos; i a Mariana; i a Don Tomas Tamayo en su docta defensa.

Uma primeira exclusão a fazer da análise de Faria e Sousa em 1639 é a presença de autores como Juan de Mariana e Tomas Tamayo, uma vez que estes são posteriores a 1580. A estas referências juntam-se Geógrafos subtilmente mencionados (em VIII, 29) e o Epigrama de Ausónio (III, 100) ${ }^{79}$. Contudo, há que delimitar o vasto campo de ocasiões em que Tartessos surge, circunscrevendo-o à identificação desse nome com a cidade de

79. Na verdade, Ausónio fornece duas referências a Tartessos. No epigrama 6 (invitatio ad paulum): «(...) Paule, Camenarum celeberrime Castaliarum/ alumne quondam, nunc pater,/ aut avus, aut proavis antiquior, ut fuit olim tartesiorum regulus». ou, traduzido: «(...) Paulus - once the most famous child of the Castalian Camenae, now their father or grandfather, as was of old the kinglet of Tartessus». Mais adiante (XXIII), diz que «Condiderat iam Solis equos Tartesia Calpe/ stridebatque freto Titan iam segnis Hibero». Ou, traduzido: «Now had Tartessian Calpe hidden the Sun's coursers and Titan, now feeble, plunged hissing 'neath the Iberian wave». As traduções são de Hugh E. White (1967). 
Carteia (= Tarifa) e com um rio, prescindindo de outros - igualmente importantes - registos ${ }^{80}$. Tal implica ter em consideração as informações que o poeta teve à sua disposição durante o seu «honesto estudo» ou, em última análise, na sua «larga experiência» de vida. A análise deste aspecto implica, consequentemente, ponderar as interpretações sobre Tartessos com as quais pode ter tido contacto.

Em 1672, João Franco Barreto desenvolve um comentário mais minucioso, não se referindo a qualquer história ou crónica espanhola, como Faria e Sousa, mas procurando apontar paralelos com outros autores. Referindo-se aos Tartesios Campos, «Os de Andalusia, chamada assi de Tartesso, lugar antiquissimo de Espanha, que delle se chamou tambem Tartesia; e Avieno por esa rasam chama Tartesio ao rio Betys. Plinio no proemio do livro terceyro, Tito Libio, lib. 8. Pomponio Mela lib. 2 dizem, que Tartesia he a mesma que Carteia (que he Tarifa como acima dissemos) mas Silio Itálico as divide $(. .$.$) em o Livro 3(.).)^{81}$.

A relação Tartessos $=$ Cidade $=$ Carteia tem como representantes Apiano (Ib. 63), Estrabão (III 2, 14), Mela (II, 5, 96), Plínio (Nat. III, 7) e Sílo Itálico (III, 396), três dos quais, como vimos, explicitamente expostos por LC em V, 50.

O leque de obras que relacionam Tartesso com um rio é mais amplo: Argonáuticas Órficas (1242), Aristóteles (Mete. 350a. 36), Avieno (OM 215 - 225; 252 259; 267 - 302), Escimno (Éforo, 164), Estêvão de Bizâncio (s.v. Tartêssós), Estrabão (III 2, 11), Macróbio (Sat. V, 21, 19), Pausânias (VI, 19, 3) e Estesícoro de Himera (Gerioneida, $P M G$ 184).

Vimos atrás a possibilidade de uma recepção indirecta dos textos antigos em LC. Podemos, por isso, recorrer a uma hipótese que foi sugerida por Américo Costa Ramalho (1975) num artigo intitulado «Sobre o nome de Adamastor»: O Dictionarium de Aelius Antonius Nebrija (apud Fernandes, 1980: 7, n. 12; Ramalho, 1980a: 10-11) $)^{82}$, actualmente disponível na Biblioteca Nacional de Portugal (=BNP). Consultaram-se as edições microfilmadas de 1520, 1536, 1543 e 1545, procurando identificar alterações e acrescentos nos termos Baetica, Carteia e Tartessos (com os respectivos derivados). O lapso cronológico destas edições é, creio, suficiente para obter uma boa visão de conjunto sobre

80. Continua a ser de extrema utilidade a obra editada por Jaime Alvar e J.M. ${ }^{a}$ Blázquez (1993), onde se apresenta um detalhado corpus sobre as referências literárias a Tartessos, da responsabilidade de M. ${ }^{a}$ M. Myro (p. 201 - 214). Veja-se, igualmente, Blázquez, 1969

81. Apresenta-se, mais adiante, esta citação de Silio Itálico.

82. A acrescentar a Gramática de Nebrija, que não foi consultada neste trabalho. a questão aqui tratada, e pode ser enquadrado no que antes mencionei sobre a introdução da obra de Nebrija no meio universitário português.

Em relação directa com o assunto que nos importa, Martí - Aguilar (1996: 84-5) comenta que «Nebrija (...) se integra también entre los historiadores semi-oficiales de Fernando el Católico, y ejemplifica en gran medida la dialéctica historiográfica que en parte heredarán los historiadores del siglo XVIII. Pese a su excelente formación clásica, se sentía profundamente obligado respecto a su patria (...). En su opinión, España ha sido un imán para los invasores desde los tiempos primitivos, siendo hasta su tiempo presa y botín de los extranjeros. Lógicamente, el fin de esta situación y con ello la restitución de la unidad de España desde sus orígenes, se encarnaría en los Reyes Católicos»». Vejamos, então, os termos que tivemos oportunidade de consultar na sua obra.

Tarifa não aparece mencionada no Dictionarium, mas surge, por exemplo, como vulgo de Carteia na edição de 1545, impressa em Antuérpia, bem como no Dictionarium Latino - Hispanicum et vice versa Hispanico - Latinum, numa posterior edição de 1570, também impressa em Antuérpia, associada a Tartessos (i.e.. Tartessus $=$ Carteia $=$ Tarifa $)$. Esta e outras explicações encontram-se dispersas, entre significados e edições, do modo exposto na tabela 2 :

A partir desta pequena amostra, verifica-se que, entre 1520 e 1536, surgem dois novos termos relacionados com Tartessos, dos quais se destaca tartessius, $a$, um. LC utiliza os campos tartésios partindo, provavelmente, da formulação de equidade Tartessos = Cidade da Bética $=$ Carteia, utilizando tartessius a partir de uma edição posterior a 1520. Mesmo a edição de 1536 viu a luz do dia quando LC teria doze ou treze anos de idade, o que equivale a dizer que podia ser consultada em Coimbra, partindo do pressuposto que terá havido, como vimos, liberdade de opção para a escolha da obra de Nebrija a partir de 1525 .

A utilização de Tarteso dá também a entender que o poeta recorreu ao termo latino Tartessus, que surge com esta forma na edição de 1545 , substituindo a fórmula grega com terminação em -os, presente nas edições anteriores (1520a, 1520b, 1536 e 1543). Ou seja, LC pode ter tido acesso a um Dictionarium como este que tivemos oportunidade de assinalar, sem, necessariamente, ter recolhido essas informações em todos os autores «clássicos» (ou de alguns deles), visto que tanto a interpretação do termo n'Os Lusíadas como a etimologia empregue parecem ir de encontro a este documento.

Vejamos outra hipótese possível. A 1 de Outubro de 1548, a casa de Domenico de Robertis (Sevilha) 
Tabela 2: Bétis, Carteia e Tartessos em várias edições do Dictionarium de Nebrija

\begin{tabular}{|c|c|c|c|c|c|}
\hline & \multirow{2}{*}{\multicolumn{5}{|c|}{ Edições }} \\
\hline & & & & & \\
\hline Termo no Dictionarium & $1520 \mathrm{a}$ & $1520 \mathrm{~b}$ & 1536 & 1543 & 1545 \\
\hline Baetica regio est Hispaniae quam Baetis ficat & $\mathrm{x}$ & $\mathrm{x}$ & $\mathrm{x}$ & $\mathrm{x}$ & \\
\hline $\begin{array}{l}\text { Baetica tertia pars Hispaniae sica Baeti flu. Dicta vulgo el Reyno de } \\
\text { Granada. }\end{array}$ & & & & & $\mathrm{x}$ \\
\hline Baeticus, a, um. Adject. Ut color Baeticus hoc est. & & & & & $\mathrm{x}$ \\
\hline Baeticus, a, um. Res ad Baeticam pertinens. & & & $\mathrm{x}$ & & \\
\hline Baetis fluuius à quo Baetica prouincia dicta & $\mathrm{x}$ & $\mathrm{x}$ & $\mathrm{x}$ & $\mathrm{x}$ & \\
\hline $\begin{array}{l}\text { Baetis, fluuius Hispaniae a quo Baetica prouincia dicta vulgo } \\
\text { Guadalquebir }\end{array}$ & & & & & $\mathrm{x}$ \\
\hline Carteia ciuitas fuit Hispaniae ad Calpe & $\mathrm{x}$ & $\mathrm{x}$ & $\mathrm{x}$ & $\mathrm{x}$ & \\
\hline Carteia, ciuitas Hispaniae ad Calpen Plinio. Vulgo Tariffa & & & & & $\mathrm{x}$ \\
\hline *Tartessiacus, a, um. Sil. It Tartessiacus tendit ad littora portus & & & $\mathrm{x}$ & $\mathrm{x}$ & \\
\hline *Tartessius, a, um. Ouid. Prefferat occiduas tartessia littora phoebus & & & $\mathrm{x}$ & $\mathrm{x}$ & \\
\hline Tartessos civitas est baeticae aedem quae Carteia & $\mathrm{x}$ & $?$ & $\mathrm{x}$ & $\mathrm{x}$ & \\
\hline Tartessos idem est qui Baetis pottea dictus & $\mathrm{x}$ & $?$ & $\mathrm{x}$ & & \\
\hline Tartessus, ciuitas est Baeticae aedem quae Carteia Põp. [Mela] & & & & & $\mathrm{x}$ \\
\hline Tartessus, ide[m] est q[uae] Betis pottea dictus. Guadalquebir & & & & & $\mathrm{x}$ \\
\hline Cota de Microfilme BN: & F2417 & F2408 & F2322 & F2323 & $\mathrm{F} 2315$ \\
\hline
\end{tabular}

termina a impressão do Libro de Grandezas y cosas memorables de España ${ }^{83}$, de Pedro de Medina. Este realiza um estudo interessante sobre o passado da sua «España», no qual valoriza particularmente a (também sua) Andaluzia, bem como a explicação etimológica de vários nomes atribuídos às várias regiões espanholas $\mathrm{e}$ "lusitanas".

É momento de relembrar a hipótese proposta por Epifânio Dias no seu comentário a III, 17. Logo no primeiro capítulo («Como España es principio y cabeça de

83. Graças aos esforços das funcionárias da Biblioteca Nacional, foi possível consultar esta obra na edição original de 1548 . Na sua apresentação destaca-se um mapa esquematizado da Península Ibérica, representando cidades, regiões e acidentes geográficos. Regista-se também a presença de quatro barcos na área do Mediterrâneo e um junto à baía de Cádiz. Devo apontar que o artigo de Sabio González (2003) baseia-se nos comentários posteriores (1595) de Diego Pérez de Mesa, transcrevendo um texto que se encontra alterado pelo comentador e que não corresponde, ipsis verbis, à edição original de 1548 . No entanto, esta alteração não parece comprometer o sentido do texto. todas regiones del mundo de su assiento y figura»), surge uma descrição geral da Península Ibérica que recorre à mesma representação ginecomórfica já assinalada:

«[España] es principio y cabeza de todas las otras regiones del mundo. Esto muestran algunos autores, entre los quales, uno es Plino Veronense ${ }^{84}$ que en el libro que hizo de la discreción del mundo dize: la redondez de la tierra se divide en tres partes: que son Europa, Africa y Asia y para decir destas comiença

84. Pedro de Medina recorre a uma tradição local de Verona, que pretendia assinalar ali o local de nascimento de Plínio. cf.Paratore, 1987: 687. A passagem de Plínio a que se refere identifica-se em Nat. III, 3: «Terrarum orbis universus in tres dividitur partes, Europam, Asiam, Africam. origo ab occasu solis et Gaditano freto, qua inrumpens oceanus Atlanticus in maria inferiora diffunditur. hinc intranti dexterea Africa est, laeva Europa, inter has Asia. termini amnes Tanais et Nilus.XV p. in longitudinem quas diximus fauces oceani patent, $\mathrm{V}$ in latitudinem, a veco Mellaria Hispaniae ad promunturium Africae Album, auctore Turranio Gracile iuxta genito» (http://www. thelatinlibrary.com/pliny.nh3.html, cons. 16 de Outubro de 2009). 
de España así como principio y cabeza dellas (...). Ptholomeu philadelfo señalando estas tres partes del mundo que dichas son, lo primero comie[n]ça en Europa: y de Europa la primera regiõ que señala es España (...). También le muestra ter España principio, y cabeza de todas las otras regiones».

O Cap. II («De los nombres que España há tenido; y del que ahora tiene, y porquese llama así») vai de encontro ao Genesis bíblico desde Adão e Eva, passando pelo episódio da Torre de Babel. A partir daí, explica como Ibéria deriva de Ebro (segundo Ptolomeu) e Hispéria deriva ou do Rei Hespero ou do nome da estrela (Espero) que guiou Tubal até à Andaluzia ${ }^{85}$. A partir daí, criavam-se condições para introduzir (no Cap. III) a descendência de Jafet ${ }^{86}$ a partir da obra de Flávio Josefo, que dá a Tubal o nome de Teobel (Ant., I, 2) ${ }^{87}$. Pedro de Medina utiliza o nome Jobel/ Jobeles: «y dice [Josefo] que del se llamaron Jobeles los que después se llamaron Iberos» (Cap. III). De acordo com esta leitura, Tubal impôs, neste percurso, bondade, virtude e leis no melhor território: a Andaluzia. Aqui terá tido um filho chamado Ibero ${ }^{88}$. Esta mesma

85. «Aunque algunos dizen que se dio assi: porque cuando Tubal y sus compañeros a ella vinieron tuvierõ advertencia en una estrella que se llama Espero que en cierto tiempo parece en la parte occidental» (Cap. II, f. 1v). Mais adiante, o autor refere o nome de Tubal, desta vez associado a Setúbal (na sua ortografia, «Setubar»), pela semelhança entre o topónimo e o antropónimo. Este aspecto foi, por várias vezes, valorizado nas tentativas de explicar o actual nome de Setúbal, conhecida como Caetobriga pelos romanos.

86. Esta tradição está presente na obra de Rodrigo Ximénez de Rada ou El Toledano (1170 - 1247), intitulada De Rebus Hispaniae, iniciando «el proceso de gestación de un determinado modelo de visión de la Antigüedad que culminará en Ocampo» (Martí-Aguilar, 1996: 80). Posteriormente, a Crónica General de Alfonso X el Sabio, no século XIII (c. 1270 e ampliada em c. 1289) afirma que existem varios Héracles, destacando-se o Tebano, o Tírio e o Argivo (id. Ibid.: 81). É o primeiro que LC parece ter em linha de conta quando apresenta deste modo o Estreito de Gibraltar: «Com Tingitânia [Espanha] entesta, e ali parece/ que quer fechar o mar Mediterrano,/ onde $o s a$ bido estreito se enobrecel co'o extremo trabalho do Tebano». Esta ideia coincide também com a de Pedro de Medina.

87. Ou seja, a descendência de Noé e Jafet chegou a Cádiz, «ocupando las tierras que encontraban a su paso y, como nadie había habitado antes esos lugares, designaron a estos pueblos con sus propios nombres». Acrescenta que «También Teobel fundó a los Teobelos, que actualmente reciben el nombre de Iberos» (I, 2; trad. J. Vara Donado, 1997)

88. Os capítulos seguintes tratam da explicação para a diminuição da longevidade dos homens (Cap. IV) e para os nomes dos primeiros reis espanhóis (Cap. V). A partir destes reis, inicia-se um discurso que visa explicar nomes de cidades (Brigo, que originou os topónimos em -briga), rios (Tago = Tejo, pai de Beto = Bétis $)$, bem como a genealogia da realeza espanhola (Gérion, Héracles, Hispal, etc.), justificando um capítulo inteiro dedicado a Gárgoris (VI) e Habis ou Abilis (VII). Segue-se o despovoamento e repovoamento de Espanha (VIII), bem como a exposição das «gentes estrañas que en preocupação repete-se no Cap. LIX («De la prouincia Lusitania y Reyno de Portugal»), onde expõe os mesmos aspectos que LC no Canto III relativamente à descendência de Luso (para Pedro de Medina, $16^{\circ}$ Rei de Espanha) ${ }^{89}$

Através destes exemplos, é possível assinalar a utilização da informação de Mela relativamente à associação Carteia $=$ Tartessos, no Cap. XXVII $(«$ De la prouincia de Andalucia y de los nombres que a tenino y del que ahora tiene y de las cosas notables della»). Como no resto do Libro, o autor cita as obras em que se baseia para explicar o nome da Bética, destacando a sua fertilidade agrícola (que motivou a escolha do primeiro estabelecimento de Tubal) ${ }^{90}$ e metalífera (citando Aristóteles) $^{91}$. Aqui entra o interesse Fenício, cujos navegantes «tomaron tierra sobre la parte donde moravã los españoles andaluzes llamados tartessios; cuyo sitio era junto a Tarifa» (o sublinhado é meu).

É, porém, no Cap. XXXII que Pedro de Medina dedica um capítulo a esta cidade («de la villa de Tarifa de su nõbre y cosas notables que en ella a auido»), reintroduzindo a relação entre Tartessos e Tarifa, e introduzindo o topónimo de Tarteya, uma provável corrupção de Cartheya ${ }^{92}$. Esta opinião deve ser confrontada com o exemplo de um manuscrito de De Chorographia, de Pompónio Mela, com tradução de Joan Faras e apontamentos de Duarte Pacheco Pereira (autor de Esmeraldo de Situ Orbis): «El seno e la cueua es adelante, en el es Tarteya (segun que algunos piensan), y alguna vez Tartesos, e aquellos que los Feniçes traidos de Africa habitan (...)» (Codex 50-v-19 da

diversos tiempos vinierõ en España, y como los Españoles salieran para muchas partes fuera della» (IX).

89. Pedro de Medina refere também Viriato (no Libro, «Variato, hombre muy animoso»), no qual se detém mais, e continua em D. Afonso Henriques (ff. 65 - 67). Destaca, dentro da Lusitânia, o Algarve (LX), Lisboa (Cap. LXI), Tejo (LXII), Setúbal (LXIII), Hircana (LXIV), Coimbra (LXV), Viseu (LXVI), Guimarães (LXVII) e Porto (LXVIIII).

90. «Desta prouincia dize Ptolomeo que primero se llama Betica por el río Betis que por ella corre que ahora llamamos Guadalquibir. Según otros dizen que se llamo assi por el rey Beto (...). Algunos historiadores hablan sobre razón del nombre de Betica y dicen que esta prouincia no fue llamada así por causa ni del río Betis ni del rey Beto. Sino porque fue vocablo Caldeo que deciende de Behin. El cual vocabulo según se halla en el libro de las intepretaciones Ebraicas quiere decir tierra fértil y deleitossa. Qual es esta prouincia que por la sobrada fertilidad de todas las cosas llevo crecida ventaja sobre quantas en el mundo se saben tanto que los poetas pasados fingían en sus libros ser enella que los cãpos Eliseos dõnde dezian que las animas de los bienaventurados venían».

91. Mais precisamente, Mir. 135, embora Pedro de Medina não o refira.

92. «A tres leguas de Algezira a la parte del poniente es la villa de Tarifa que se llamó primero Tarteya, después Tartesso». 
Biblioteca da Ajuda, fl. 25v, apud Carvalho, 1974: 33, n. 5; texto: 178$)^{93}$.

Nesta linha de pensamento, Ocampo também destaca o interesse fenício em Tartessos, referindo a importância de Argantónio, governante dos «vecinos de Tarifa» (Ocampo, ed. 1791, I. 342 - 3, apud Martí Aguilar, 2000: 17).

O conhecimento de Mela e de outros autores que, como Plínio ou Estrabão, procuram localizar a antiga cidade Peninsular no território observado, é confirmado na obra intitulada De Platano (1527), que chegou a Coimbra em 1536, com a fundação da Universidade. Nesta «são repetidos de mistura autores clássicos e humanistas, como na parte escrita em 1527, por exemplo, Dioscórides, Pompónio Mela, Estrabão, Nicandro, Varrão, Virgílio, Plínio, Macróbio, entre gregos e latinos, e Eneias Sílvio, Flávio Biondo, Hermolao Bárbaro, Marcelo Virgílio, Pontano, Nebrija, Célio Rodigino, entre os humanistas» (Ramalho, 1980a: 6 - 7; o sublinhado é meu) ${ }^{94}$. Para além disso, saliente-se que terá circulado em Portugal a obra de Estrabão, numa edição publicada em Basileia $(1523)^{95}$.

A outra vertente é apresentada em VIII, 29, em que Tarteso é o nome de um rio («Entre o Tarteso e o Guadiana») e parece definir uma região que coincide, precisamente, com a Bética de acordo com a divisão provincial romana. Como vimos, Tartessos/ Tartessus surge no Dictionarium de Nebrija como Bétis.

Em nenhuma destas referências surge uma relação de Bétis com Tartessos. Ou, por outras palavras, se o nosso poeta procurou o primeiro termo no Dictionarium, não teria chegado ao segundo. No entanto, nesta obra há, como vimos, a referência a Silio Itálico, assinalada também por J.F. Barreto, que cita esta passagem de Púnicas III, 396 - 400:

Arganthoniacos armat Carteia nepotes./ rex proauis fuit humani ditissimus aeui,/ ter denos decies emensus belliger annos./ armat Tartessos stabulanti conscia Phoebo,/ et Munda, Emathios Italis paritura labores ${ }^{96}$.

93. Publicação ao encargo de Joaquim Barradas de Carvalho (1974). O manuscrito, na versão latina, apresenta-se assim: «Sinus ultra est, in eoque Carteia ut quidam putant aliquando Tartessos, et quam transvecti ex Africa Phoenices habitant (...)» (apud Carvalho, 1974: 32). Tive oportunidade de confirmar que, na edição bilingue da Chorographia de A. Silberman (1988), o texto refere, igualmente, Carteia e não Tarteia. Tratar-se-ia de uma interpretação posterior que procurava assimilar Carteia a Tartessos, alterando o $\mathrm{C}$ inicial?

94. Veja-se também o interessante artigo de A.C. Ramalho publicado nos Estudos sobre o século XVI (1980b: 20), sobre «A introdução do Humanismo em Portugal» (p. 1 - 20).

95. Cf. a Exposição Bibliográfica (1972: 216 - 7).

96. Na edição da Micrologia, «Phoebo» surge como «Phaebo». Pode tratar-se ou de uma leitura menos precisa dos editores, ou mesmo
Podem acrescentar-se outras referências de Púnicas, importantes pelo facto de conterem os termos Tartessiaco $(\mathrm{VI}, 1)^{97}$ e Tartessius $(\mathrm{X}, 537)^{98}$. Este último termo, como também assinala Nebrija, surge em Ovídio (Met. XIV, 416) como designação de «Oceano ocidental tartéssico» ${ }^{99}$.

Como foi referido anteriormente, Estrabão (III 2, 11) refere Tartessos como um rio associado ao Bétis: «Parece que los antiguos llamaban al Betis Tartesos y a Gádira e islas cercanas Eritía» (Trad. M. ${ }^{a}$ J. Meana e Félix Piñero, 1992).

«Na estância 29 refere-se o poeta ás batalhas de Aljubarrota (1-4) e de Valverde (5-8), cujo vencimento é, com razão, atribuído ao conselho e valentia de $\mathrm{D}$. Nuno, e ainda outro elemento - a sorte -, que bem sobressai da leitura de F. Lopes». É com estas palavras que Rodrigues (1905: 296) inicia o seu comentário a VIII, 29, acrescentando que o epíteto infinita podia derivar da ideia que Fernão Lopes transmite sobre a superioridade numérica dos inimigos (Crón. $2^{\mathrm{a}}$ p., cap. 56).

A referência a Tartessos exclui-se, como vemos, da análise de Rodrigues, o que motiva a exclusão de Fernão Lopes, tal como ocorreu antes com Rui de Pina para III, 100 (cf. supra). Ou seja, mesmo admitindo que Lopes tenha sido uma fonte do poeta para assinalar a vitória de D. Nuno sobre a gente que «entre o Tarteso e o Guadiana habita», não podemos afirmar que esta seja a fonte da referência para Tartessos.

Apesar de sabermos que estas fontes antigas estariam acessíveis em textos latinos ou traduzidos, a coincidência

do próprio J.F. Barreto, que não cita o último verso. Tanto na edição online do texto latino de S. It. (http://www.thelatinlibrary.com/silius/silius3.shtml) como na tradução de J.D. Duff (1961) o termo é «Phoebo». Este último traduz assim esta passagem: «Carteia sent to war the children of Arganthonius; king over their ancestors, he surprassed all the mankind in lenght of days and waged war for the space of three hundred years. Tartessus, that sees the sun to rest, sprang to arms; and likewise Munda, doomed to produce for Italy the suffering of Pharsalia».

97. «Iam, Tartessiaco quo solverat aequore Titam/ in noctem diffusus (...)»: «Now on Eastern shores the Sun was yoking the steeds that he had freed in the sea of Tartessus when he scattered his fires for the night» (Pun. III 1-2, trad. J.D. Duff, 1961).

98. Retirou-se um excerto mais alargado: «Funereas tum deinde pyras certamine texunt,/ officium infelix et munus inane peremptis,/ donec anhelantes stagna in Tartessia Phoebus/ mersit equos, fugiensque polo Titania caecam/ orbita nigranti traxit caligine noctem»: «Down came oaks and pine-trees that love the shore, and cypresses that deck the funeral train and mourn beside the pire $-\mathrm{s}$ mournful duty and a tribute that means nothing to the dead - until Phoebus plunged his panting seeds in the waters of Tartessus» (X, 535-539).

99. «Sparserat occiduus Tartessia litora Phoebus». Cf. Blázquez, 1969: 99, onde comenta que este excerto pode sugerir a navegação Tartéssica no Atlântico ou, simplesmente, por banhar as suas costas. Para uma edição online do texto de Ovidio, veja-se http:// www.thelatinlibrary.com/ovid/ovid.met14.shtml. 
das interpretações camonianas de Tartessos, bem como a utilização de uma provável adaptação de tartessius a tartésio, com o Dictionarium de Nebrija, permitem pensar nesta obra como uma possibilidade relativamente sólida. Não quero, com isto, excluir o Libro de Grandezas de Pedro de Medina ou outras fontes supostamente disponíveis para o poeta. As restantes obras de síntese (De Platano, por exemplo) devem, por isso, ser analisadas de futuro, pois podem conter informações importantes. Como tal, e antes de encerrar este texto com uma nota final, queria reforçar a ideia de que este texto apresenta resultados que devem ser aprofundados num âmbito de investigação e discussão mais alargado.

\section{NOTA FINAL}

«Original é o poeta / de origem clara e comum/ que sendo de toda a parte/ não é de lugar algum./ O que gera a própria arte/ na força de ser só um/ por todos a quem a sorte faz/ devorar um jejum./ Original é o poeta/ que de todos for só um.»

Ary dos Santos

«Não mais, Musa, não mais, que a lira tenho/ destemperada e a voz enrouquecida,/ e não do canto, mas de ver que venho/ cantar a gente surda e ensurdecida./ O favor com que mais se acende o engenho, não no dá a Pátria, não, que está metida/ no gosto da cobiça e na rudeza/ duma austera, apagada e vil tristeza».

Os Lusiadas X, 145

A leitura d'Os Lusídas impõe alguns desafios a um «profano», obrigando à consulta de textos que não se enquadram na minha formação académica, mas que vão ao encontro da minha sensibilidade. Acima de tudo, a análise aqui proposta recaiu sobre um poeta que não foi, suficientemente, valorizado no seu tempo, não obstante o legado literário que deixou para a posteridade, como se vê em IX, 145, que, por sua vez, parece representar o olhar do poeta sobre os seus contemporâneos.

Verificámos, ao longo do caminho percorrido até aqui, que é extremamente difícil definir uma fonte possível para a inclusão de Tartessos n'Os Lusíadas. A formação do poeta, supostamente em Coimbra, pode levar a pensar que a obra de Nebrija foi tida como um ponto de partida possível, ensinando-se, a partir daí, o significado de Tartessos enquanto rio (Betis/Guadalquivir) ou cidade (Carteia/Tarifa). Contudo, ficará sempre por esclarecer a leitura directa, por parte de LC, dos textos antigos que levaram a estas considerações. Um outro aspecto levantado por esta investigação foi a possível leitura do Libro de Pedro de Medina, já que existem algumas pistas que permitem estabelecer alguma relação com este (a descrição da Europa Ginecomórfica, a preocupação por definir a origem dos nomes e a relação Tartessos/ Carteia, etc.), ou mesmo com outros textos (como o de Florián de Ocampo, 1541; 1543; 1553), visto que, como aponta Martí-Aguilar (1996: 79 - 80, n. 9), a História oficial produzida com os Áustrias é precedida por uma série de intentos que remontam ao período dito Medieval.

Deste modo, mesmo apresentando o Dictionarium de Latim, publicado por Nebrija em várias edições, como hipótese mais provável, não creio que seja prudente descartar outras aproximações. Como também não é de descartar a hipótese de aquisição de algumas informações por via oral, como aliás fez Castanheda, que viveu (como LC) na Índia.

Podemos assinalar que não teria qualquer interesse para a construção do poema atingir o rigor com que Pedro de Medina e Florián de Ocampo, por exemplo, tratam a questão. Sobretudo porque o discurso épico do poeta vai mais de encontro às preocupações da Historiografia portuguesa do que, propriamente, às da Historiografia espanhola. É que, do lado espanhol, o advento do Estado Moderno conduziu a repensar a conjuntura e intervenção políticas, bem como a organização social, o que se reflectiu na imagem que o poder dos Habsburgo pretendia transmitir da sua História. O poeta português, consciente da mensagem que transmitiu no seu poema, nunca poderia juntar-se a um propósito expansionista que ameaçava a independência da «Lusitânia».

Estas diferenças ao nível dos interesses do discurso reflectem-se no percurso histórico definido num e noutro país. A Historiografia espanhola parece dar um sentido bíblico à sua História, recuando os primórdios a Jafet, Tubal e seus descendentes, ligando-os também ao mundo clássico, personalizado por Héracles (egípcio) ${ }^{100}$.

Por outro lado, LC não recuou mais do que a Luso (para Pedro de Medina, $16^{\circ}$ rei de Espanha), já que seria a partir daqui que explicaria o nome de Lusitânia. Já André de Resende havia assinalado a palavra Lusíadas para definir esta questão, baseando-se, como tivemos oportunidade de ver, na informação sobre Luso em Plínio. É, provavelmente, com base nesta informação que LC integra Luso no seu esquema histórico. O que pode revelar que é possível identificar uma correspondência entre o pensamento camoniano e, por exemplo, o de Plínio, ou mesmo de Mela ou de Estrabão. O caminho que essa mesma informação faz pode ser diferente, dispensando a consulta directa de qualquer um destes autores.

Fica, contudo, por responder de que modo esta exclusão pode ser intencional, e se LC estaria, ou não,

100. Cf. Martí - Aguilar, 1996: 85 ss. 
a par do esquema genealógico iniciado em Jafet. De qualquer modo, Tartessos enquadra-se num esquema histórico orientado para a luta contra o Mouro e contra o Castelhano, em que se valoriza a Cristandade e a independência, representadas por D. Afonso Henriques e Nuno Álvares Pereira nos Cantos III e IV.

Talvez por este motivo não encontremos tão-pouco uma valorização de Tartessos enquanto património da memória colectiva portuguesa, ou mesmo enquanto factor identitário dos Lusíadas. No entanto, nas duas ocasiões em que Tartessos surge, é em contextos históricos, e como referente geográfico. Na linha de abordagem utilizada neste trabalho, creio que há motivos para pensar numa escolha fundamentada na métrica, visto que qualquer uma das alternativas a campos tartésios ou Tarteso não permitia que a $6^{\mathrm{a}}$ e a $10^{\mathrm{a}}$ sílabas fossem tónicas.

Mesmo considerando todos estes aspectos, valorizando uns e desvalorizando outros, podemos retirar daqui uma pequena ilação: que LC pode ser integrado na história da recepção de Tartessos na literatura ibérica do século XVI.

Ponderando as hipóteses apresentadas para as «fontes» camonianas, creio que é mais seguro inclinarmonos para a consulta do Dictionarium de Nebrija, uma vez que tanto a interpretação (Tartessos $=$ Betis $=$ Guadalquivir; = Carteia $=$ Tarifa) como a etimologia, aparentemente latina $($ Tartessus $=$ Tarteso ; Tartessius $=$ Tartésio), coincidem com esta obra. Vimos que estas fórmulas surgem em edições do Dictionarium por volta do tempo em que o poeta terá desenvolvido o seu «honesto estudo». O uso da obra de Nebrija estendese também a dois exemplos (Tarraconense $=$ Aragão e Adamastor) e merece, a meu ver, um estudo sistemático que permitisse assinalar outros mais.

$\mathrm{Na}$ pesquisa efectuada, procurei verificar se, na bibliografia activa do poema, podia identificar-se algum estudo sistemático da presença de autores como Mela, Plínio e Estrabão, o que não ocorreu. O mesmo acontece com a relação entre Os Lusíadas e alguns aspectos pontuais da Historiografia espanhola, que pode ser um caminho a percorrer, não obstante as diferenças que tivemos oportunidade de apontar.

Deixo este texto com uma série de incertezas e lacunas que poderão vir a ser colmatadas no futuro, tanto com o desenvolvimento da minha investigação pessoal, como com a crítica que pode ser feita a este texto. Esta contribuição é, fundamentalmente, o resultado de um estudo que considerei aliciante. Espero que tenha conseguido transmitir, através das palavras que escrevi, o mesmo encanto com que me debrucei sobre a presença de Tartessos n'Os Lusíadas.

\section{REFERÊNCIAS}

AAVV (1980): Luís de Camões. Exposição bibliográfica comemorativa do IV Centenário da sua morte. 4 vols. Biblioteca Municipal do Porto, Porto.

AGUIAR E SILVA, V.M.P. (1962): Para uma interpretação do classicismo. Coimbra Editora, Coimbra.

ALBUQUERQUE, L. DE (1981): "Sur quelques textes que Camões consulta pour écrire", Os Lusíadas. Arquivos do Centro Cultural Português, $3^{\mathrm{a}}$ série, $\mathrm{n}^{\mathrm{o}}$ 16: 35-50.

ALBUQUERQUE, P. (2008): Tartessos: entre Mitos e Representações. Dissertação de Mestrado em Préhistória e Arqueologia apresentada à Faculdade de Letras da Universidade de Lisboa, sob a orientação de A.M. Arruda e J.S. Horta (texto policopiado).

ALBUQUERQUE, P. (2009): “Algumas considerações em torno da construção de Tartessos em Heródoto", Gerión 27 (1): 87-121.

ALBUQUERQUE, P. (em prep.): “A philoxenia de Argantónio e de Alcínoo nos confins ocidentais do mundo habitado".

ALMEIDA, J.M. DE (1950-1951): "Sobre um virgilianismo d'Os Lusíadas", Humanitas 3: 329-343.

ALMEIDA, J.M. DE (1997): “Os Lusíadas e a épica latina”, AAVV, Épica. Épicas. Épica Camoniana: 4552. Edições Cosmos, Lisboa e Constanza.

ALVAR, J. y BLÁZQUEZ, J.M. ${ }^{\text {a }}$ (eds.) (1993): Los Enigmas de Tarteso. Cátedra, Madrid.

ALVES, H.J.S. (2001): Camões, Corte-Real e o Sistema da Epopeia Quinhentista. Centro Interuniversitário de Estudos Camonianos, Coimbra.

ALVES, H.J.S. (2005): "Presença da Odisseia em Camões", Revista Camoniana, $3^{\mathrm{a}}$ série, no 17: 39-47.

AMORA, A. (1973): "A crítica feita ao poema no decurso da história literária", Actas da I Reunião de Camonistas: 175-206. Comissão Executiva do IV Centenário da Publicação de Os Lusíadas, Lisboa.

AMORA, A.S. (1980): "Análise retrospectiva e prospectiva dos estudos camonianos em 1980", Brotéria 111: 5-18.

BALLABRIGA, A. (1986): Le soleil et le Tartare. L'image mythique du monde en Grèce Archaïque. EHESS, Paris.

BARRETO, J.F. (1982): Micrologia Camoniana. Prefácio de Aníbal Pinto de Castro, leitura e integração do texto de Luís Fernando de Carvalho Dias e Fernando F. Portugal. INCM/ BN, Lisboa.

BERARDINELLI, C. (2000): “Ourique, Salado e Aljubarrota", Estudos Camonianos: 57-70.

BERNAL, M. (1993):Atenea Negra. Las raíces afroasiáticas de la civilización clásica, Vol. I, La 
invención de la Antigua Grecia, 1785 - 1985. Crítica, Barcelona.

BIVILLE, F. \& DANGEL, J. (1997): “L’écriture épique latine: propositions pour une lecture stylistique", Evphrosyne 25: 389-414.

BLÁZQUEZ, J.M. (1969): "Fuentes griegas y romanas referentes a Tartessos", Tartessos. V Symposium Internacional de Prehistoria peninsular. Jerez de la Frontera, septiembre, 1968: 91-110.

BREMOND, C. (1966): "La logique des possibles narratives", Communications 6 (1): 60-76.

CAMPOS, J.A.S. (1998): "The classical background of Portuguese epic Poetry in the 16th and 17th centuries", Evphrosyne 26: 121-134.

CARVALHO E SILVA, M. (1984): “Algumas notas relativas à evolução dos estudos camonianos", IV Reunião Internacional de Camonistas: 643-657. Universidade dos Açores, Ponta Delgada.

CARVALHO, J.B. DE (1974): La traduction espagnole de «De situ Orbis» de Pomponius Mela par maître Joan Faras et les notes marginales de Duarte Pacheco Pereira. Junta das investigações científicas do Ultramar, Lisboa. .

CARVALHO, J.L. DE (1980): “Os Lusíadas, epopeia neovirgiliana”, Separata de Brotéria 111 (5): 393-418.

CASTELO-BRANCO, F. (1982): "A História de Lisboa em Os Lusiadas", Lisboa Revista Municipal, Ano 43, 2a série, $n^{\circ}$ 2: 24-30.

CASTELO-BRANCO, F. (1984): “A visão camoniana da história”, IV Reunião Internacional de Camonistas: 115-132. Universidade dos Açores, Ponta Delgada.

CASTRO, A. (1984): “Camões e a tradição poética peninsular”, IV Reunião Internacional de Camonistas: 133-152. Universidade dos Açores, Ponta Delgada.

CASTRO, A.P. DE (2004): "Boscán e Garcilaso no lírismo português do Renascimento e do Manierismo", Península: Revista de Estudios Ibéricos 1: 65-96.

CHASSIGNET, M. (1998): "Historiographie et écriture épique", Evphrosyne 26: 155-163.

CIDADE, H. (1942): "Prof. Doutor José Maria Rodrigues", Revista da Faculdade de Letras, 2a série, Tomo VIII, ${ }^{\circ}$ 1/2: 6-11.

CIDADE, H. (1981): "Juan de Mena e Luís de Camões", A. Peixoto (ed.), Ensaios Camonianos: 121 123. LISA/ INL-MEC, S. Paulo, $5^{\mathrm{a}}$ ed.

CIDADE, H. (1984): “Camões”, J.P. Coelho (org.), Dicionário de Literatura, Vol. I: 136-139. Figureinhas, Porto.

CIDADE, H. (2004): Luís de Camões. J.H. Saraiva (coord.) Biografias da História de Portugal, Vol. XXIII. Quidnovi, Lisboa.
CORREIA, M. ${ }^{\text {a }}$ S.C. (1985): Achegas para uma bibliografia sobre Camões e a sua obra. Texto policopiado.

CRUZ, A. (1984): "Portugal e a Europa no tempo de Camões", Revista de História 1: 205-216.

DASILVA, M. (1998): "Valor decisivo dos manuscritos para o cânone camoniano: alguns exemplos a partir da Poesia Española”, I Congresso Internacional de estudos camonianos: 237-288. UERJ/SBLL, Rio de Janeiro.

DIAS, A.E.S. (1972): Os Lusíadas de Luís de Camões comentados por (...). Reprodução fac-similada da $2^{a}$ edição (em dois tomos - 1916/1918). Prefácio de Arthur Cezar Ferreira Reis; estudo prévio de Maximiano de Carvalho e Silva. Ministério da Educação e Cultura, Lisboa.

DIAS, J.S.S. (1981): Camões no Portugal de Quinhentos. Biblioteca Breve/ ICLP, Lisboa.

EXTREMERA TAPIA, N. (1998): "A fortuna nas letras espanholas de um verso de Os Lusíadas", I Congresso Internacional de estudos camonianos: 195-218. UERJ/SBLL, Rio de Janeiro.

EXTREMERA TAPIA, N. (2005): "Juan de Mena e Luís de Camões: do castelhano para o português e do português para o español", Revista Camoniana, $3^{a}$ série, Vol. 18: 57-80. São Paulo.

FARIA E SOUSA, M. (1972): Lusíadas de Lvis de Camões comentadas por (...). Edição fac-similada da edição de 1639. Introdução de Jorge de Sena, 2 Vols. IN/CM, Lisboa.

FERNANDES, R.M.R. (1980): “Camoëns et l'héritage classique", Arquivos do Centro Cultural Português, $3^{a}$ série, $n^{\circ} 15: 3-24$.

FERREIRA, M. ${ }^{\text {a }}$ E. T. (1998): Vasco da Gama na literatura dos Descobrimentos. Leitura, selecção de textos, organização, introdução e notas de [...]. Ulisseia, Lisboa.

FIGUEIREDO, A.C. B. DE (1883a): A Geographia dos Lusíadas de Luis de Camões. Typographia de Adolfo, Modesto \& Ca., Lisboa.

FIGUEIREDO, A.C. BORGES DE (1883b): Carta da Geographia dos Lusíadas de Luis de Camões. Typographia de Adolfo, Modesto \& Ca., Lisboa.

FLASCHE, H. (1973): "O método de comentar de Manuel de Faria e Sousa (contributo para a interpretação d' "Os Lusíadas»", Actas da I Reunião de Camonistas: 135-174. Comissão Executiva do IV Centenário da Publicação de Os Lusíadas, Lisboa.

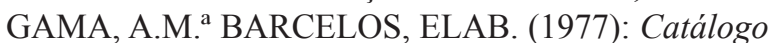
da Biblioteca do "Real Colégio de São Pedro" de Coimbra, 2 vols. BGUC, Coimbra.

Gonçalves, F.R. (1950-1951): “Tito Lívio e Camões", Humanitas 3: 259-277. 
GUERRA, A. (1995) Plínio-o-Velho e a Lusitânia. Colibrí, Lisboa.

LAVOURA, M. ${ }^{\mathrm{a} E}$. (2001): Tipografia espanhola do século XVI. A colecção da Biblioteca Nacional. Biblioteca Nacional, Lisboa.

LÁZARO CARRETER, F. (1980): “Imitación y originalidad en la poética renacentista", F. Rico (dir.) e F. López Estrada (coord.), Historia y crítica de la $\mathrm{Li}$ teratura Española: 91-97. Editorial Crítica/ Grupo editorial Grijalbo, Barcelona.

LEMOS, A.V. \& ALMOYNA, P. (s.d.): A Obra espanhola de Camões (estudo crítico), $2^{\mathrm{a}}$ ed. Pax, Porto e Braga.

LIVERMORE, H.V. (1984): "Notas sobre o poeta e sua familia", IV Reunião Internacional de Camonistas: 311-318. Universidade dos Açores, Ponta Delgada.

LOURENÇO, F. (2004): "Camões, leitor da Odisseia?”, Grécia Revisitada: 259-266. Cotovia, Lisboa.

LOURENÇO, J.D.M.D. (1999): “A descoberta dos Antigos no Renascimento: o caso particular de Ptolemeu", Evphrosyne, nova série, no 27: 339-350.

MARTÍ-AGUILAR, M. A. (1996): La Antigüedad en la historiografía española del siglo XVIII: el Marqués de Valdeflores. Universidad de Málaga, Málaga.

MARTÍ-AGUILAR, M. A. (2000): La Imágen de Tartessos en la Historiografía Española (Siglos XVI $X X)$. Texto policopiado.

MARTÍN ABAD, J. (1991): La Imprenta en Alcalá de Henares (1502 - 1600), 3 vols. Arco/ Libros, Madrid.

MARTÍN BAÑOS, P. (2006): "Los conceptos de imitación y originalidad antes del romanticismo", C.M. Cabanillas (coord.), Actas de las IV Jornadas de Humanidades Clásicas: 285-292.

MARTÍNEZ, M. (1999): "Las islas de los Bienaventurados: Historia de un mito en la literatura griega arcaica y clásica", $C F C-E G I$ 9: 243-279.

MATOS, M. ${ }^{a}$ V. (1995): Bibliografia Camoniana, 19801985. Separata de Românica 4.

MATOS, M. ${ }^{a}$ V.L. DE (1983): Poesia épica de Camões. Tópicos para a leitura d' «Os Lusíadas». FAOJ, Algueirão.

MEDINA, P. DE (1548): Libro de las grandezas y cosas memorables de España. Ahora de nuevo fecho y copilado por el Maestro Pedro de Medina Vezino de Sevilla. Dirigido al sereníssimo y muy esclarecido Señor, D. Filipe Príncipe de España. En casa de Domenico de Robertis, Sevilla.

MENDES, J. (1999): "Imitação", Verbo. Enciclopédia Luso - Brasileira de Cultura, Edição século XXI: 55-556. Verbo, cols, Lisboa, S. Paulo.
MILLER, N. (1972): “Os Lusíadas e o Cancioneiro Peral”, Ocidente, n.s., Ano 34, $\mathrm{n}^{\mathrm{o}}$ especial, Novembro: 99-122.

MYRO, M. ${ }^{a}$ M. (1993): "Los enigmas de Tarteso: apéndices documentales", J. Alvar y J.M. ${ }^{a}$ Blázquez (eds.), Los Enigmas de Tarteso: 201-214. Cátedra, Madrid.

OCAMPO, F. DE (1541): Las quatro partes enteras de la Cronica de España. Agustin de Paz y Juan Picardo: a costas e expensas de Juan de Espinosa, Zamora.

OCAMPO, F. DE (1543): Los quatro libros primeros de la Cronica general de España que recopila el maestro Florian do campo criado y cronista del Emperador Rey nuestro señor por mandado de su magestad Çesarea. Juan Picardo, Zamora.

OCAMPO, F. DE (1553): Los quatro libros primeros de la Cronica general de España que recopila el maestro Florian do campo coronista del Rey nuestro señor, por mandato de su Magestad, en Zamora. Medina del Campo.

OLIVEIRA, P.F.M. (1998): "Literatura e História em Os Lusiadas", I Congresso Internacional de estudos camonianos: 409-427. UERJ/SBLL, Rio de Janeiro.

Os Lusíadas, 1572 - 1972. Catálogo da Exposição bibliográfica, iconográfica e medalhística de Camões. Prefácio de M. L. de Almeida, Introdução, selecção e notas bibliográficas por J.V. de Pina Martins. IN-CM, Lisboa.

PEIXOTO, A. (1932): Ensaios camonianos. Universidade, Coimbra.

PEREIRA, M. ${ }^{a}$ H. DA R. (2007a): "Presenças da Antiguidade Clássica em Os Lusíadas", Camoniana Varia: 61-81.Centro Interuniversitário de Estudos Camonianos, Coimbra.

PEREIRA, M. ${ }^{a}$ H. DA R. (2007b): “O «honesto estudo» de Camões", Camoniana Varia: 5-8. Centro Interuniversitário de Estudos Camonianos, Coimbra.

PINA MARTINS, J.V. (1981): “O Humanismo na obra de Camões", Arquivos do Centro Cultural Português, $3^{\mathrm{a}}$ série, $\mathrm{n}^{\mathrm{o}} 16$ : XVII-XXIX.

PINHO, S.T. DE (2007a): "Camões e Virgílio: débito e criatividade na disposição narratológica d' Os $L u$ síadas em face de Envida", Decalogia Camoniana: 119-131. Centro Interuniversitário de Estudos Camonianos, Coimbra.

PINHO, S.T. DE (2007b): “A descrição camoniana da Europa e a cartografia ginecomórfica", Decalogia Camoniana: 133-170. Centro interuniversitário de Estudos Camonianos, Coimbra.

PIRES, C. (1999): "Imitação", Verbo. Enciclopédia Luso-Brasileira de Cultura, Edição século XXI: 556-557. Verbo, cols., Lisboa, S. Paulo. 
PIRES, M. ${ }^{a}$ L.G. (1982): A crítica camoniana no século XVII. ICALP, Lisboa.

POST, H.M. (1972): “A cronologia da composição de várias passagens de Os Lusíadas”, Ocidente 83: 293-316.

PROPP, V. (ed.) (2006): Morfología del Cuento. Editorial Fundamentos, Madrid.

RAMALHO, A.C. (1971-1972): “A introdução do Humanismo em Portugal”, Humanitas 23-24: 435-452 [reimp. Em Ramalho, 1980b: 1-20].

RAMALHO, A.C. (1979): "Sobre a cultura de Camões", Colóquio. Letras 47: 70-73.

RAMALHO, A.C. (1980a): Estudos Camonianos, $2^{2}$ ed. Coimbra.

RAMALHO, A.C. (1980b): Estudos sobre o século XVI. Fundação Calouste Gulbenkian, Paris.

RAMALHO, A.C. (1981-1982): “Alguns aspectos da vida universitária em Coimbra nos meados do século XVI (1548-1554)", Humanitas 33-34: 3-30.

RAMALHO, A.C. (1984): "Camões e o Humanismo Renacentista", IV Reunião Internacional de Camonistas: 485-501. Universidade dos Açores, Ponta Delgada.

RAMOS, E.P. (2000): Os Lusíadas de Luís de Camões. Edição organizada por (...). Porto Editora. Porto.

REBELO, L.S. (1980): A Tradição Clássica na Literatura Portuguesa. Livros Horizonte, Lisboa.

RIBEIRO, O. (1980): “Camões e a geografia”, Finisterra XV: 153-199.

RODRIGUES, J. M. a (1979): Fontes dos Lusíadas. $2^{\mathrm{a}}$ Ed. Prefácio de António da Costa Ramalho. Academia das Ciências de Lisboa, Lisboa.

SABIO GONZÁLEZ, R. (2003): "La historia de Tarifa según dos autores del siglo XVI: Pedro de Medina y Diego Pérez de Mesa", Aljaranda: Revista de estudios Tarifeños 50: 9-14. Tarifa.

SALGADO JÚNIOR, A. (1950): “«Os Lusíadas» e o tema das Argonáuticas (I - ideia dum problema; II Esboço da sua história)", Ocidente 38: 277-294.

SALGADO JÚNIOR, A. (1951): “«Os Lusíadas» e o tema das Argonáuticas (III - Primeiros aspectos da Lição recolhida de Valério Flaco: do sonho de D. Manuel ao aparecimento do Adamastor)", Ocidente 40: 261-284.

SENA, J. DE (1980): A Estrutura de «Os Lusíadas»e outros estudos camonianos e de poesia peninsular do século XVI, $2^{\mathrm{a}}$ ed., [1 ${ }^{\mathrm{a}}$ ed. 1970]. Edições 70, Lisboa.

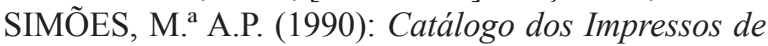
Tipografia Portuguesa do século XVI. A colecção da Biblioteca Nacional. Biblioteca Nacional, Lisboa.

SOARES, M. ${ }^{a} L$. DE C. (2004): "Providencialismo Histórico e Ideias Político-Sociais n'Os Lusíadas de Camões", Humanitas 56: 433-459.

UNIVERSIDADE DE COIMBRA (1970): Catálogo dos reservados da Biblioteca geral da Universidade de Coimbra. Por ordem da Universidade, Coimbra.

VASQUEZ CUESTA, P. (1981): “O bilinguismo castellano-português na época de Camões", Actas do Centro Cultural Portugués 16: 807-828.

VILÀ I TOMÀS, L. (2001): Épica e imperio. Imitación virgiliana y propaganda política en la épica española del siglo XVI. Tesis doctoral dirigida por María José Vega Ramos. Universitat Autònoma de Barcelona.

WEST, M.L. (1988): "The Rise of the Greek Epic", Journal of Hellenic Studies 112: 151-172.

WILLIS, R.C. (1972): “«Os Lusíadas» and its Neoclassical critics”, Ocidente 83: 269-293.

FECHA DE ENTRADA: 17-11-2009

FECHA DE ACEPTACIÓN: 28-12-2009 